\title{
An Empirical Look at Commander Bias in Sexual Assault Cases
}

\author{
Eric R. Carpenter*
}

In response to the American military's perceived inability to handle sexual assault cases, the Uniform Code of Military Justice is undergoing its most significant restructuring since its creation in 1950. Critics point to the high rates of sexual assault case attrition as a sign that the system is failing sexual assault victims. The theory is that commanders are predisposed to believe the offenders and to blame the victims. This bias then causes high levels of attrition as the commanders undervalue the cases and divert them from the legal process.

This study tests that causal inference. It measures the attrition of sexual assault cases in the precise phase of the case processing that the commanders control-the decision to take action in the case. Using data received from the Army through the Freedom of Information Act, this study measures how commanders disposed of every founded sexual assault and sexual contact offense in the Army from 2008-2011. Further, this study tests the counterfactual-how commanders treated other similar cases: homicides, robberies, and assaults.

This study reveals that commanders treat non-penetrative sexual assaults the same or more seriously than they treat simple assaults. Further, when commanders decide to take action on penetrative sexual assault cases, commanders send more of those cases to trial than they do with comparable crimes. However, commanders decide to take no action in penetrative sexual assault cases more frequently than they do with other comparable crimes. This study includes a secondary finding that commanders treat domestic violence cases more seriously than they treat

DOI: https://dx.doi.org/10.15779/Z38SN01433

Copyright (C) 2017 Regents of University of California

* Associate Professor of Law, F.I.U. College of Law. I thank Dale Williams, Stephanie Garcia, and the F.I.U. Department of Biostatistics, Ann McGinley, and my research assistant, Kimberly Laica. This paper benefited from comments provided at workshops at the Texas Tech University School of Law and the Law and Society Association 2016 Annual Meeting. 
other similar assault cases.

The results of this study should inform the national debate on whether Congress should take the last, major step in restructuring the military justice system: removing commanders from the process. These results suggest that step may not be necessary because commanders do not appear to be introducing bias into the system.

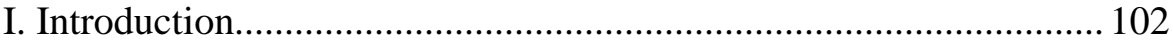

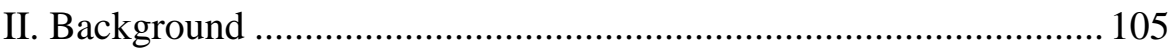

A. Researching Attrition.............................................................. 105

B. Attrition in Sexual Assault Cases ......................................... 107

C. Bias Causes Attrition? ........................................................ 108

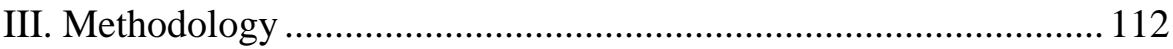

A. Causal Reasoning and Counterfactuals ................................ 112

B. Counterfactual Studies on Sexual Assault Attrition ............ 119

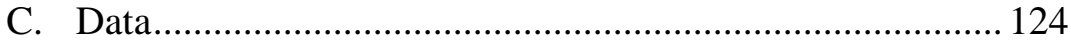

D. Hypothesis ……………………………………….......... 129

IV. Findings …………………………………………………....... 131

V. Discussion and Conclusion ........................................................... 136

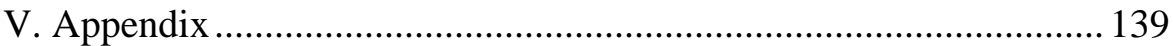

A. Data Screening and Reduction................................................. 139

B. Explanation of Crime Categories............................................... 143

1. Penetrative and Non-penetrative Sexual Assaults ........... 143

2. Murder ……………………………………………..... 144

3. Manslaughter ……………………………………….... 144

4. Robbery …………………………………………..... 145

5. Aggravated and Simple Assaults ..................................... 145

\section{INTRODUCTION}

In response to the American military's perceived inability to handle sexual assault cases, the Uniform Code of Military Justice (UCMJ) is undergoing its most significant restructuring since its creation in 1950. Critics point to the high number of sexual assault cases that drop out of the system as a sign that commanders are failing sexual assault victims. The critics have in mind the non-stranger, consent-defense cases - where male soldiers commit sexual assaults against female soldiers ${ }^{1}$ who they

\footnotetext{
1 Men are also victims. During the period of this study, roughly $10 \%$ of reported sexual assaults involved male victims. In almost all of those cases, the offender was also male.
} 
know, and the offender claims the victim consented. The critics' theory is that commanders are predisposed to believe the offenders and to blame the victims. This bias then causes high levels of attrition as the commanders undervalue the cases and divert them from the legal process.

This perception has driven reform. Already, Congress has rewritten the UCMJ's sexual assault provisions to focus the prosecutor's attention on the offender's behavior rather than the victim's, ${ }^{2}$ changed the pretrial hearing procedures to greatly limit the scope of that hearing (which in the past often included a cross-examination of the victim), ${ }^{3}$ and severely curtailed a commander's authority to disapprove of a courtmartial's findings and sentence. ${ }^{4}$ In turn, the President has limited the commander's use of an accused's good military character when deciding how to dispose of a case, ${ }^{5}$ and the factfinder's use of that evidence during the guilt phase of the trial. ${ }^{6}$

The low-hanging fruit is now gone, and the remaining target for reform is the centerpiece of American military justice-the commander's authority to decide whether a case should be prosecuted. In 2014, Senator Kirsten Gillibrand nearly succeeded in her effort to take that authority away from commanders and give it to military prosecutors, ${ }^{7}$ and similar proposals will likely come forward again. ${ }^{8}$

U.S. Dep't of Def., Annual Report on Sexual Assault in the Military app. D (2012); U.S. DeP'T OF DeF., ANNuAl Report ON SEXUAl AsSAUlt in the Military, Aggregate Statistical MAtrices 3, 87 (2011); U.S. DeP’T OF DEF., ANNUAL REPORT on Sexual Assault in the Military 77 (2010); U.S. Dep'T OF DeF., Report on SeXual Assault in the Military app. C (2009). Male-on-male sexual assault in the military is a serious issue; however, the general narrative that critics advance to achieve reform involves male-on-female sexual assault, and that narrative will be the focus of this article.

2 UCMJ art. 120 (2012).

3 National Defense Authorization Act for Fiscal Year 2014, Pub. L. No. 113-66, § 1702 (2013).

4 Id.

5 Infra note 126.

6 Infra note 127.

7 Military Justice Improvement Act of 2013, S. Res. 1752, 113th Cong. § 2(a) (2013). After a fairly public battle, this bill fell five votes short of the sixty votes required to defeat a filibuster. Amanda Marcotte, What Happened to the Military Sexual Assault Bill in the Senate on Thursday?, SLATE (Mar. 7, 2014, 10:57 AM), http://www.slate.com/blogs/xx_factor/2014/03/07/military_sexual_assault_bills_c laire_mccaskill_defeats_kirsten_gillibrand.html.

8 Samantha Bee recently featured Gillibrand's continued efforts to pass the bill on Bee's television show. Full Frontal with Samantha Bee (Comedy Central television broadcast June 6, 2016), https://www.youtube.com/watch?v=HxxU99ajH3c. 
This study tests for bias at the exact stage of the process that the commander controls - the prosecutorial decision on what action to take in the case. ${ }^{9}$ Using data provided by the U.S. Army for all founded reports between 2008 and 2011, this study tests the assumption that bias causes attrition at this stage by comparing the decisions commanders made in sexual assault cases (to take no action, administrative action, nonjudicial action, or judicial action) with the decisions that they made in other comparable cases that involve violence against the victim (homicides, robberies, and assaults). If commanders choose less serious actions in sexual assault cases than in these other offenses, then that suggests that bias exists. Removing the commanders from the system, as sought by Senator Gillibrand, would remove this bias.

However, this study finds that commanders process nonpenetrative sexual assaults the same as or more seriously than simple assaults. For these cases, commanders do not appear to be introducing bias into the system. The picture for penetrative sexual assaults is more complex. When commanders take action in these cases, commanders send more of those cases to trial than they do with manslaughter, robbery, and aggravated assault cases. That decision does not appear biased; however, commanders decide to take no action in these cases more frequently than they do with comparable crimes. In that one area of processing, bias appears to exist.

These results inform the national debate on whether Congress should take the last, major step in restructuring the military justice system: taking the prosecutorial decision-making from commanders and giving it to military lawyers. These results suggest that step may not be necessary. Bias does not appear to be pervasive.

Still, one possibility is that bias operates earlier in the system-at the stage that law enforcement controls. Law enforcement officials may be the ones screening out otherwise meritorious cases. If so, commanders may only see the strongest sexual assault cases, which would make their

9 In sexual assault cases, the initial stages of investigation are run by an independent, military detective service (for the Army, the Criminal Investigation Command (CID)). See Lawrence J. Morris, Military Justice: A Guide to the Issues 47-48 (2010). Once the investigation is complete, CID sends the case to the commander. U.S. ARMY, Health Promotion, Risk Reduction, Suicide Prevention 47 (2010) [hereinafter, HeAlth Promotion]. The commander, rather than the prosecutor, ultimately decides what happens to the case. The commander receives advice from a military attorney, and while the commander often follows that advice, he or she is not bound by it. See MoRRIS, supra, at 58-59. If the military attorney is biased, that bias could enter the system at this point. 
decisions easier and which would make it hard to detect pervasive bias at this later stage. More research is needed to see if bias operates at this earlier stage of law enforcement processing.

This study also includes an important secondary finding: across the board, commanders process domestic violence cases more seriously than they process other assault cases. The military was once under scrutiny for its handling of domestic violence cases ${ }^{10}$ and responded to that criticism with changes in policy and by resourcing programs to address domestic violence. The data suggests that the military has improved its handling of domestic violence cases.

In Part II, this article introduces the concept of attrition, how it is used in the study of sexual assault case processing, and how critics use attrition studies to claim that bias causes attrition. In Part III, this article discusses counterfactual reasoning, how it can support causal inferences, and prior counterfactual research on sexual assault case attrition; describes the data used in this study; and provides the study's hypothesis. In Part IV, this article details the study's findings and, in Part V, concludes with policy implications.

\section{BACKGROUND}

\section{A. Researching Attrition}

Attrition is the rate at which cases are lost or dropped from the legal process, ${ }^{11}$ from the moment of the offense to sentencing. Attrition is generally studied at six points, ${ }^{12}$ and researchers use different data sources to measure attrition at these different points. The first point of attrition is whether the victim reports. Researchers generally use surveys to measure this attrition. In the United States, the survey that is frequently used is the National Crime Victimization Survey, which is administered annually by the U.S. Census Bureau for the Bureau of Justice Statistics. ${ }^{13}$

10 See generally Amy Herdy \& Miles Moffeit, Betrayal in the Ranks, DENVER PosT, Feb. 4, 2004, http://extras.denverpost.com/justice/tdp_betrayal.pdf.

11 Jeanne Gregory \& Sue Lees, Attrition in Rape and Sexual Assault Cases, 36 BRIT. J. CRIMINOLOGY 1 (1996).

12 Susan J. Lea et al., Attrition in Rape Cases: Developing a Profile and Identifying Relevant Factors, 43 BRIT. J. CRIMINOLOGY 583 (2003). For an index of attrition studies, see Kathleen Daly \& Brigitte Bouhours, Rape and Attrition in the Legal Process: A Comparative Analysis of Five Countries, 39 CRIME \& JUST. 565 app. A (2010).

13 Bureau of Justice Statistics, Data Collection: National Crime VICTIMIZATION SURVEY, http://www.bjs.gov/index.cfm?ty=dcdetail\&iid=245 (Jul. 11, 2016) [hereinafter, NCVS]. 
If the offense is reported to the police, the second and third points of possible attrition occur while law enforcement controls the case. These are the decisions to unfound ${ }^{14}$ the case or to later clear the case by exceptional means. Under the Federal Bureau of Investigation (FBI) reporting guidelines, police should only unfound a case "when, after a thorough investigation, the investigator finds that no crime occurred because the report was false or baseless." ${ }^{15}$ Unfounded cases drop out of the system; founded cases continue to the next stage.

The next point of possible attrition is the police decision to clear the case. Agencies clear cases by arrest (to arrest, charge, and send to a court for prosecution) or by exceptional means. ${ }^{16}$ Agencies can clear by exceptional means if the investigation established the identity of the offender, the exact location of the offender is known, and there is enough information to clear by arrest, but there is some reason outside law enforcement control that precludes clearing by arrest. ${ }^{17}$ These reasons could be the offender's death, lack of jurisdiction over the offender, or the victim refuses to cooperate. ${ }^{18}$ These cases should be as strong as the cases that are cleared by arrest; the difference between them is only that the agency cannot make the arrest for some reason.

Cases cleared by exceptional means drop out of the system. Cases that have enough information to exceed the "unfounded" threshold but not enough to be cleared by arrest or by exceptional means, and cases that do have enough information but where the offender cannot be identified or found, remain unsolved. Researchers generally use data from the Uniform Crime Reports (UCR) (or similar data sets), case files, or interviews with police officers to measure the founding and clearance attrition points.

The fourth point of attrition is the focus of this study: this is the point where the prosecutor (or in the military, the commander) decides to take the case to trial or to dismiss the case. Because the UCR does not measure attrition at this stage of the legal process, researchers have to find another source of data, and generally, they measure this attrition by gaining access to and then coding individual case files. Importantly, the U.S. Army crime reporting system directly records this point of attrition,

14 British law enforcement uses the phrase "no-crime” instead of "unfound."

15 U.S. DEP'T OF Justice, Uniform CRIME REPORTING HANDBOOK 77 (2004)

[hereinafter, UCR HANDBOOK].

16 Id. at 150 .

17 Id. at 78, 80.

18 Id. at 80. 
and I will be using its data for this study.

The fifth and sixth points of attrition occur at trial. The fifth is during the merits phase (with acquittals) and the sixth is during sentencing (with no jail time). Researchers generally gain access to and then code individual case files to measure this attrition, although the U.S. Government occasionally tracks this data. ${ }^{19}$

\section{B. Attrition in Sexual Assault Cases}

Researchers and commentators compile the results of each stage of attrition to report on attrition as a whole and, for sexual assaults, it appears that very few cases survive the system to the point where an offender spends time in jail. Lonsway and Archambault report that for every 100 forcible rapes, $5-20 \%$ will be reported, $0.4-5.4 \%$ will be prosecuted, $0.2-5.2 \%$ will result in conviction, and $0.2-2.8 \%$ will result in incarceration. $^{20}$

The Department of Defense reports attrition at each stage of the military justice process. ${ }^{21}$ If we roughly convert the military's attrition flow $^{22}$ to the Lonsway and Archambault format, of 100 sexual offenses

19 See Mark Motivans, U.S. DeP’t of Justice, Federal Justice Statistics, 2012 StATISTICAL TABlEs (2015); MARK MOTIVANS, U.S. DEP'T OF JUSTICE, FEDERAL JUSTICE Statistics, 2011—STATistical TABles (2015); MARK Motivans, U.S. DeP’T of Justice, Federal Justice Statistics, 2010-Statistical Tables (2013); MARK Motivans, U.S. DeP'T of Justice, Federal Justice Statistics, 2009-Statistical TABLES (2011); U.S. DEP'T OF JusTiCE, COMPENDIUM OF FEDERAL JustiCE STATISTICS, 2001 (2003); Barbara Boland ET AL., U.S. DeP'T OF Justice, The Prosecution of FELONY ARRESTS, 1988 (1992).

20 Kimberly A. Lonsway \& Joanne Archambault, The “Justice Gap” for Sexual Assault Cases: Future Directions for Research and Reform, 18 ViolenCE AGAINST WOMEN 157 (2012); see also Daly \& Bouhours, supra note 12, at 568. Researchers often represent this attrition graphically with an inverted triangle or funnel chart. See Lonsway \& Archambault, supra, at 145, 157; JOANNA BOURKE, RAPE: SEX, VIOLENCE, HiSTORY 395 (2007); Jessica HARris \& SHARON GraCE, A Question of EvidENCE? INVESTIGATING AND PROSECUting RAPE IN THE 1990s 43 (HOME OFFICE RESEARCH STUDY 196) (1999).

21 U.S. DeP'T OF Def., AnNual Report On SeXual Assault in the Military (2014) [hereinafter, DOD ANNUAL REPORT].

22 For 2014, the Department of Defense reported a very rough estimate that 18,900 service members were the victims of a sexual offense. The term "sexual offense" includes the penetrative offenses of rape and aggravated sexual assault and the non-penetrative offenses of abusive and wrongful sexual contact, as well as attempts to commit these offenses. Id. at app. A, fig.5, tbl.2. The Department of Defense computes this number by taking the prevalence rates for unwanted sexual contact and applying those rates to the military population. $I d$. at 8 . The prevalence rate for women was $4.3 \%$ and for men was $0.9 \%$. Id. Women make up about $15 \%$ of the military population, or about 200,000 service members. By the Numbers: Women in the U.S. Military, CNN (Jan. 24, 2013, 5:27 PM), 
that are committed, $25 \%$ will be reported without restriction, $3 \%$ will be prosecuted, just over $2 \%$ will result in conviction, and just under $2 \%$ will result in incarceration.

\section{Bias Causes Attrition?}

According to feminist critical theory, bias causes this attrition. ${ }^{23}$ The seed for the bias is beliefs about gender roles and, more particularly, the acceptance of rape myths. Rape myths are attitudes and beliefs about rape that "are generally false but are widely and persistently held, and that serve to deny and justify male aggression against women." ${ }^{44}$ These include beliefs that only deviant men rape; men cannot control their

http://www.cnn.com/2013/01/24/us/military-women-glance/. Men make up 85\%, or about 1,200,000 service members. Id. Multiplying the prevalence rates against those population figures, roughly 8,600 women and 10,800 men were victims of a sexual offense. Because the military population is so large, small changes in the prevalence rate can lead to large changes in the total estimate, and that number should be interpreted with caution.

The military received 4,660 unrestricted reports where either the victim or offender was in the military. DoD ANNUAL REPORT, supra note 21, at app. A, p. 15. Unrestricted reports are discussed infra at note 125 and accompanying text. The 18,900 figure only includes military victims, but the offender could have been military or civilian. The 4,660 figure only includes military offenders, but the victim could have been military or civilian.

Of these 4,660 unrestricted reports, the military identified 3,217 suspects that were subject to military authority. Id. at app. A, fig.10. Of these, 528 of the allegations were unfounded by legal review, and the military let other jurisdictions handle 64 suspects, leaving 2,625 suspects. Of these, 998 were charged with a sexual offense and 588 went to court-martial on a sexual offense. Id. at app. A, fig.14. Of these, 434 were convicted of some offense (not necessarily a sexual offense) and, of these, 317 received some form of confinement. Id. at app. A, fig.14.

This is a rough translation. The baseline number of total assaults is subject to significant swings because of how it is computed; the baseline number includes about $56 \%$ male victims but the attrition numbers are likely to include mostly female victims; and the baseline number includes only military victims and includes civilian offenders while the attrition figures include only military offenders but also include civilian victims.

23 David Bryden \& Sonja Lengnick, Rape in the Criminal Justice System, 87 J. CRIM. L. \& CRIMINOLOGY 1194, 1195-98 (1997); Darrel J. Steffensmeier, The Uniqueness of Rape? Disposition and Sentencing Outcomes of Rape in Comparison to Other Major Felonies, 72 Soc. \& Soc. REs. 192 (1988); Jim Galvin \& Kenneth Polk, Attrition in Case Processing: Is Rape Unique?, 20 J. Res. CRIME \& DELINQ. 126 (1983); Martha A. Myers \& Gary D. LaFree, Sexual Assault and Its Prosecution: A Comparison with Other Crimes, 73 J. CRIM. L. \& CRIMINOLOGY 1282, 1283-84 (1982); Gerald D. Robin, Forcible Rape: Institutionalized Sexism in the Criminal Justice System, 23 CRIME \& DELINQ. 136 (1977).

${ }^{24}$ Kimberly A. Lonsway \& Louise F. Fitzgerald, Rape Myths: In Review, 18 PsYCHOL. WOMEN Q. 133, 134 (1994). 
sexual urges; the woman wanted it or deserved it; women lie about rape; no harm was done; or that certain events do not qualify as "real" rape. ${ }^{25}$

These beliefs lead to bias in case processing that favors male offenders and disfavors female victims. Research indicates that people who endorse rape myths are inclined to side with the man and question the woman in sexual assault cases. According to critics, when law enforcement officials are influenced by rape myths, they will side with the man and let cases drop out of the system. ${ }^{26}$

When looking at the discrete decision-making process that people use when resolving sexual assault cases, researchers have focused on three clusters of factors: those related to the case (such as the use of a weapon, injury to the victim, forensic evidence available, witnesses available, or victim participation); those related to victim characteristics (demographics and behavior before, during, and after the assault); and those related to defendant characteristics (demographics and relationship to victim). ${ }^{27}$

Research suggests that decision making in sexual assault cases is affected by a combination of these factors, with a few discrete factors appearing to have causal significance. ${ }^{28}$ Generally, a case is more likely to make it through the system if the victim is physically injured or a weapon is used; or, if the evidence against the suspect is strong, where the strength of the evidence is often measured by the victim's willingness to participate, the availability of other witnesses, and the availability of

25 Diana L. Payne et al., Rape Myth Acceptance, 33 J. RES. PERSONALITY 27, 49-50 tbl.2 (1999); Martha R. Burt, Rape Myths and Acquaintance Rape, in ACQUAINTANCE RAPE: The Hidden CRIME 26 (Andrea Parrot \& Laurie Bechhofer, eds. 1991).

26 See Eric R. Carpenter, The Military’s Sexual Assault Blind Spot, 21 WASH. \& LEE J. Civ. Rights \& SoC. JuST. 383, 390-401 (2015).

27 Cassia Spohn \& David Holleran, Prosecuting Sexual Assault: A Comparison of Charging Decisions in Sexual Assault Cases Involving Strangers, Acquaintances, and Intimate Partners, 18 JusT. Q. 651, 667-68, 671 (2001). Some researchers categorize these as legal factors (factors related to the elements of the crime) and extralegal factors (factors related to the victim and defendant). See April Pattavina et al., Examining Connections between the Police and Prosecution in Sexual Assault Case Processing, 11 Victims \& OfFENDERS 315, 317 (2016); Donald Johnson et al., Use of Forensic Science in Investigating Crimes of Sexual Violence: Contrasting Its Theoretical Potential with Empirical Realities, 18 Violence Against Women 193, 198-99 (2012); Daly \& Bouhours, supra note 12, at 609; Rodney Kingsnorth et al., Adult Sexual Assault: The Role of Racial/Ethnic Composition in Prosecution and Sentencing, 26 J. CRIM. JUST. 359 (1998).

28 Johnson et al., supra note 27, at 198-99; Spohn \& Holleran, supra note 27, at 676. 
forensic evidence. $^{29}$

While those factors appear legitimate and free of explicit bias, research suggests that these factors serve as the entry points for latent bias. $^{30}$ When they are present in a case, they tend to corroborate the victim's account ${ }^{31}$ and cast the case within the generalized image of what a rape case is supposed to look like; ${ }^{32}$ however, that image is itself shaped by rape myths. ${ }^{33}$ When those factors are present, the case is also more attractive for law enforcement and particularly for prosecutors because they may be more likely to get a conviction. ${ }^{34}$

The flip side of this is that when these factors are not present, law

29 Johnson et al., supra note 27, at 198-99; Spohn \& Holleran, supra note 27, at 676; Cassie Spohn et al., Prosecutorial Justifications for Sexual Assault Case Rejection: Guarding the "Gateway to Justice," 48 SoC. ProBs. 206, 226 (2001). The research also suggests that the distinction between stranger and acquaintance does not play an important role in case attrition. Johnson et al., supra note 27, at 213; Spohn \& Holleran, supra note 27, at 668; Rodney Kingsnorth et al., Sexual Assault: The Role of Prior Relationship and Victim Characteristics in Case Processing, 16 JusTiCE Q. 275, 296 (1999); Patricia A. Frazier \& Beth Haney, Sexual Assault Cases in the Legal System: Police, Prosecutor, and Victim Perspectives, 20 LAW \& HuM. BeHAV. 607, 618-19 (1996). For a survey of studies that have explored these factors, see Daly \& Bouhours, supra note 12, at app. C, tbl.C1.

30 Steffen Bieneck \& Barbara Krahe, Blaming the Victim and Exonerating the Perpetrator in Cases of Rape and Robbery: Is There a Double Standard?, 26 J. INTERPERSONAL VIOLENCE 1785, 1793-94 (2011) (studying a group of students and applying the same factors to rape and robbery, found that "perpetrators of robbery were blamed more than perpetrators of rape and that victims of rape were blamed more than victims of robbery”); see generally Daly \& Bouhours, supra note 12, at 615-16; Spohn et al., supra note 29, at 208-09; Katrin Hohl \& Elisabeth A. Stanko, Complaints of Rape and the Criminal Justice System, 12 EUROPEAN J. CRIMINOLOGY 324, 328 (2015); but see Myers \& LaFree, supra note 23, at 1297 (finding indications of victim sex-role conformity "did not affect reactions to sexual assaults differently from reactions to other felonies").

31 Spohn \& Holleran, supra note 31, at 668.

32 See Spohn et al., supra note 29, at 228-29, 233; Lisa Frohmann, Discrediting Victim's Allegations of Sexual Assault: Prosecutorial Accounts of Case Rejections, 38 Soc. PROBS. 213, 224 (1991) [hereinafter, Discrediting Victim's Allegations].

33 See Amy Dellinger Page, Gateway to Reform? Policy Implications of Police Officers' Attitudes Toward Rape, 33 AM. J. CRIM. JUST. 44, 53 (2008).

34 Lisa Frohmann points out that prosecutors are becoming primarily concerned with whether the case will be convictable downstream at trial. Frohmann, Discrediting Victim's Allegations, supra note 32, at 224; Lisa Frohmann, Convictability and Discordant Locales: Reproducing Race, Class, and Gender Ideologies in Prosecutorial Decisionmaking, 31 L. \& SoC’Y REV. 531 (1997); see also Johnson et al., supra note 27, at 213; Lonsway \& Archambault, supra note 20, at 159; Spohn \& Holleran, supra note 27, at 676; Kingsnorth et al., supra note 27, at 276. 
enforcement and prosecutors may think that the victim is not credible because his or her story does not fit their narrative of what a rape case should look like, and so they will not pursue the case. ${ }^{35}$ Inaction or improper action by law enforcement because of implicit bias can make the case look even worse. Because they think the case is weak, law enforcement officers may decide not to spend much effort gathering forensic evidence or locating witnesses, thereby weakening the case further. Law enforcement treatment of the victim, especially with hostile interrogations, may cause the victim to disengage from the case and ultimately end it. $^{36}$

Because the bias is implicit, "these decisions appear rational, necessary, and appropriate" to those who are working the cases. ${ }^{37}$ The law enforcement officers will genuinely think they are doing the right thing when they decide to drop what could otherwise be a meritorious case.

Critics then look to the attrition observations as proof of the theory that bias causes the attrition. For example, Joanna Bourke noted, "[w]riting this chapter [on getting away with rape] makes me angry. One statistic does it: in the U.K. today only 5 per cent of rapes reported to the police ever end in a conviction." 38 She continues, "[g]iven the huge proportion of rapes that are never even reported to the police in the first place, this is damning evidence that something is terribly wrong." 39 Looking at the attrition numbers alone, Bourke's anger seems justified.

35 Andrea Quinlan, Suspect Survivors: Police Investigation Practices in Sexual Assault Cases in Ontario, Canada, 26 WOMEN \& CRIM. JusT. 301, 307 (2016); Lucy Maddox et al., The Impact of Psychological Consequences of Rape on Rape Case Attrition: The Police Perspective, 27 J. Police Crim. Psychol. 33 (2012); Richard B. Felson \& PaulPhilippe Pare, Does the Criminal Justice System Treat Domestic Violence and Sexual Assault Offenders Leniently?, 24 Just. Q. 435, 437 (2007); Jan Jordan, Beyond Belief? Police, Rape, and Women's Credibility, 4 CRIM. JUST. 29, 51 (2004); Spohn et al., supra note 29, at 210; Barbara Krahe, Police Officers' Definitions of Rape: A Prototype Study, 1 J. COMMUnity \& APPLIED Soc. PSYCHOL. 223, 241 (1991).

36 Rebecca Campbell, What Really Happened? A Validation Study of Rape Survivors' Help-Seeking Experiences with the Legal and Medical Systems, 20 VIOLENCE \& VICTIMS 55, 61-62 (2005); see generally Quinlan, supra note 35, at 311-14; Rachel M. Venema, Police Officer Schema of Sexual Assault Reports: Real Rape, Ambiguous Cases, and False Reports, 31 J. INTERPERSONAL VIOLENCE 872, 874 (2016); LYNN LANGTON, U.S. DeP'T OF Justice, Victimizations Not Reported to the Police, 2006-2010 (2012); Rebecca Campbell, Rape Survivors' Experiences With the Legal and Medical Systems, 12 ViOlenCE AGAinst WOMEN 30, 31 (2006).

37 Frohmann, Discrediting Victim's Allegations, supra note 32, at 214.

38 BOURKE, supra note 20, at 395.

39 Id. at 389; see generally Lonsway \& Archambault, supra note 20, at 159. 


\section{METHODOLOGY}

\section{A. Causal Reasoning and Counterfactuals}

The critics' causal reasoning has a problem, though. Using the following causal inference framework, ${ }^{40}$ we can uncover the critics' reasoning problem and introduce the appropriate causal theory for this study.

The first step in the causal inquiry is to spot an anomaly that needs explanation. Here, critics say the anomaly is the high rates of attrition in sexual assault cases. The next step is a reverse causal question: what is the cause of that anomaly? ${ }^{41}$ In the sexual assault context, that reverse causal question is: what causes high rates of attrition in sexual assault cases?

When trying to answer that reverse causal question, "lots of possible hypotheses could be generated .... By a process of elimination, one can drill down to a small set of plausible causes." ${ }^{42}$ Generally speaking, researchers have obtained case files, coded possible explanatory variables, and then searched for relationships between the explanatory variables and the response variables. That research has drilled down to a small set of factors about the crime, the victim, and the offender that relates to attrition, as discussed above. Again, the theory is that law enforcement officers subscribe to rape myths, and those rape myths introduce bias in the system through the application of those factors.

Using information learned by exploring the reverse causal question, researchers can then construct models they can test with forward causal inferential reasoning. ${ }^{43}$ Where the reverse causal question asks, what is the cause of the effect, the forward causal question relates to the effect of a cause. ${ }^{44}$ In the sexual assault attrition context, that forward causal question would be: what effect does bias have on attrition? This

\footnotetext{
40 Andrew Gelman \& Guido Imbens, Why Ask Why? Forward Causal Inference and Reverse Causal Questions 2-3 (Nat'l Bureau of Econ. Research, Working Paper No. 19614, 2013).

41 Id.; see also STEPHEN L. MORGAN \& CHRISTOPHER WINSHIP, COUNTERFACTUALS AND CAUSAl INFERENCE: METHOdS AND PRINCIPLES FOR SOCIAL RESEARCH 3 (2d ed. 2015); Andrew Gelman, Causality and Statistical Learning, 117 AM. J. Soc. 955 (2011).

42 Gelman \& Imbens, supra note 40, at 4 (quoting Kaiser Fung, Causal Thinking, Numbers Rule YOUR WORLD (July 17, 2013), http://junkcharts.typepad.com/numbersruleyourworld/2013/07/causal-thinking.html).

${ }^{4} I d$. at 2 ("Once the question has been framed in terms of the effect of a specific variable, its resolution is conducted within the realm of forward causal reasoning."). 44 Id.
} 
question can be studied with the standard methods used in forward causal inferential reasoning, like randomized experiments and certain observational studies, using the standard statistical tools that are used to generate causal inferences. ${ }^{45}$

In a randomized experiment, a researcher would identify the variables that might explain the variance in sexual assault case attrition (those factors discussed above), create a model, and then manipulate those variables to see if those changes cause a variation in attrition. ${ }^{46}$ The population of interest would be law enforcement officers (for attrition at the founding and clearance stages) and prosecutors (for attrition at the prosecutorial decision-making stage), and the researcher would need to draw a random sample from the population of interest.

In that experiment, one of those variables would be beliefs about gender roles or rape myth acceptance. ${ }^{47}$ The researcher would use a scale designed to measure the acceptance of rape myths or traditional gender role beliefs and whose resulting scores predict how people resolve sexual assault cases.

The researcher would then administer a rape scenario or series of rape scenarios and ask the subjects to provide an outcome judgment- to take or not take action on the case. If subjects who scored high on the scale were less likely to take action on a sexual assault case than subjects

45 See id. at 3 ("The anomalies identified by Why questions motivate experiments and observational studies for forward causal inference and, ultimately, policy recommendations.”).

46 Paul W. Holland, Statistics and Causal Inference, 81 J. AM. STATISTICAL Assoc. 945, 946 (1986).

47 Studies have shown that some law enforcement officers subscribe to rape myths. See, e.g., Annelise Mennicke et al., Law Enforcement Officers' Perception of Rape and Rape Victims: A Multimethod Study, 29 Violence \& Victims 814, 822-23 (2014); see generally Venema, supra note 36 at 874; Ericka Wentz \& Carol A. Archbold, Police Perceptions of Sexual Assault Victims: Exploring the Intra-Female Gender Hostility Thesis, 15 PolicE Q. 25 (2012); Page, Gateway to Reform, supra note 33; Amy Dellinger Page, Behind the Blue Line: Investigating Police Officer's Attitudes Toward Rape, 22 J. Police Crim. Psychol. 22 (2007); Rebecca Campbell \& Camille R. Johnson, Police Officers' Perceptions of Rape, 12 J. INTERPERSONAL VIOLENCE 255 (1997); Rebecca Campbell, The Role of Work Experiences and Individual Beliefs in Police Officers' Perceptions of Date Rape, 23 AM. J. Community Psychol. 249 (1995); Krahe, supra note 35; John C. LeDoux \& Robert R. Hazelwood, Police Attitudes and Beliefs Toward Rape, 13 J. Police ScI. \& Admin. 211 (1985); Shirley Feldman-Summers \& Gayle C. Palmer, Rape as Viewed by Judges, Prosecutors, and Police Officers, 7 CRIM. Just. \& BeHAV. 19 (1980); Hubert S. Feild, Attitudes Towards Rape: A Comparative Analysis of Police, Rapists, Crisis Counselors, and Citizens, 36 J. PERSONALITY \& SOC. PsYCHOL. 156 (1978). 
who scored low (while controlling for the other potential explanatory variables and with statistically significant results), then we could infer that those beliefs lead to an inclination to side with the offender. That inclination is the bias.

If the population of interest were composed primarily of people who scored high on that scale, then that could explain why law enforcement organizations process the cases the way they do. ${ }^{48}$ However, if only a few people in that institution have high scores, then that would not explain the institution's behavior.

Despite years of research, "the extent to which [rape myth acceptance] influences perceptions of cases and behavioral responses is unclear." 49 Good, complete forward causal experiments do not exist, although Rachel Venema came very close to conducting one. She recently studied a population of police officers. In her study, she measured the officers' acceptance of rape myths, had the officers read one of four rape scenarios, and then measured two outcome judgments (including whether the officer would support the arrest of the suspect). ${ }^{50}$ She found that the acceptance of rape myths "is associated with lower intentions to respond

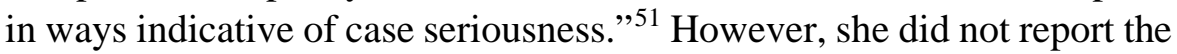
prevalence within that population of rape myth acceptance, which might then explain institutional case attrition. The population that she studied might have been filled with people who endorsed rape myths, or may have had only had a few. ${ }^{52}$

48 We still do not know if law enforcement officers subscribe to rape myths to a higher degree than the general public. See Jennifer Brown \& Joanne King, Gender Differences in Police Officers Attitudes Toward Rape, 4 Psychol. CRIME \& LAW 265, 273 (1998) (finding no difference between police and students in belief in rape myths); FeldmanSummers \& Palmer, supra note 47, at 34 (finding criminal justice system personnel subscribe to rape myths more frequently than social service personnel); Feild, supra note 47, at 175 (finding rate of police belief in rape myths to be similar to citizens' rate).

49 Rachel M. Venema, Making Judgments: How Blame Mediates the Influence of Rape Myth Acceptance in Police Responses to Sexual Assault, J. InTERPERSOnAL Violence, Aug. 2016, at 3.

50 Id. at 8-12.

51 Id. at 13.

52 In a previous study, I used existing datasets to approximate the entire experiment. Eric R. Carpenter, Evidence of the Military's Sexual Assault Blind Spot, 4 VA. J. CRIM. L. 154 (2016). In that study, I used a dataset from an experimental study similar to Venema's, except I substituted as the population of interest the general population in place of law enforcement. The original researcher measured a gender role belief, administered a survey instrument that included a dorm-room rape scenario, and measured agreement with whether the man in the scenario was guilty. I modeled that data and found that the 
While the experimental studies have not yet provided a complete answer, researchers do not have to conduct experimental studies to make a causal inference that bias causes attrition. They can still make causal inferences based on observational studies that use counterfactual reasoning. ${ }^{53}$ Causal inference based on the counterfactual or potential outcomes model is where "causality is defined via counterfactual events, or what would have happened if a certain event had been absent." 54

Currently, critics are pointing to observations about case attrition and claiming bias causes that attrition. However, to get from the attrition numbers to the conclusion that bias causes that attrition, the critics need more than an observation and a theory. The critics need to explore the counterfactual, or the potential outcomes of those cases if there were no bias operating on them.

Researchers using observational data recognized the counterfactual requirement in the early 1980s. ${ }^{55}$ Galvin and Polk noted,

A common weakness in arguments about the treatment of rape within the criminal justice system is that often the analysis focuses only upon rape. To establish the notion of a distinctive attrition in rape cases, implicit in many writings, it is necessary to compare the handling of

gender role belief caused some of the variation in the outcome judgment.

I then measured the level of that gender role belief in the military population that runs the military justice system and found that the military population held that belief to a much higher degree than the general population. I applied the coefficient for guilt regressed on the gender role belief from the earlier study to the military population, and the model predicted the percentage of the military population (that runs the military justice system) that would agree that the man was guilty as compared to the general population. This model predicted that the military population was more likely than the general population to find the man not guilty, and this suggests that bias causes some of the attrition in the military justice system.

53 Gelman \& Imbens, supra note 40, at 2 ("“C]ounterfactual reasoning can also be applied to assess contributions of past events. We label this historical reasoning as 'forward causal inference' as well, as it is based on the estimation of effects of defined treatments.”).

54 Teppei Yamamoto, Understanding the Past: Statistical Analysis of Causal Attribution, 56 AM. J. PoL. SCI. 237, 239 (2011) (emphasis in original); see also MARTINO MAgGetti ET AL., Designing ResEARCH IN the Social ScienCES 46-48 (2013).

55 Steffensmeier, supra note 23, at 192; Myers \& LaFree, supra note 23, at 1284; see also Alan J. Lizotte, The Uniqueness of Rape: Reporting Assaultive Violence to the Police, 31 CRIME \& DELINQ. 169, 170 (1985); Wallace D. Loh, The Impact of Common Law and Reform Rape Statutes on Prosecution: An Empirical Study, 55 WASH. L. REV. 543, 594 (1980). 
rape as contrasted with other felony offenses as these move through the various stages of the criminal justice process. ${ }^{56}$

In the sexual assault case attrition context, to make the causal inference, we need to know how other, similar cases - those where we hypothesize that bias does not exist-were handled. ${ }^{57}$ If other, similar cases attrit at lower rates than sexual assault cases, then we could reason that bias exists and causes attrition in sexual assault cases. ${ }^{58}$

Correspondingly, if these other, similar cases attrit at the same rate as sexual assault cases, then either the bias does not exist, ${ }^{59}$ or it does not have a causal influence on attrition. Even if law enforcement officers were predisposed to take no action, they might still handle sexual assault cases just like every other set of cases. Then, the question is simply whether all attrition rates overall are normatively too high or too low.

To make the forward causal inference, we need to measure the treatment cases (those that have been treated with the suspected bias); measure the control cases (comparable cases that have not been treated with the suspected bias); and then compare the two:

Doing so involves introducing defendable assumptions that allow for the estimation of the average unobservable counterfactual values for specific groups of [observations]. If the assumptions are defendable, and a suitable method for constructing an average contrast from the data is chosen, then the resulting average difference in the values . . . can be given a causal interpretation. ${ }^{60}$

56 Galvin \& Polk, supra note 23, at 134; see also Christopher D. Maxwell et al., The Impact of Race on the Adjudication of Sexual and Other Violent Crimes, 31 J. CRIM. JusT. 523, 525 (2003); Ronet Bachman \& Raymond Paternoster, A Contemporary Look at the Effects of Rape Law Reform: How Far Have We Really Come?, 84 J. CRIM. L. \& CRIMINOLOGY 554, 561 (1993); Susan Caringella-MacDonald, The Comparability in Sexual and Nonsexual Assault Case Treatment: Did the Statute Change Meet the Objective?, 31 CRIME \& DELINQ. 206, 209 (1985).

57 Yamamoto, supra note 54, at 241 ("When one is interested in explaining why past events happened, the goal is to make an inference about whether these particular events would not have happened in the absence of the hypothesized cause.”).

58 Id. at 239 ("From the counterfactual viewpoint, $\mathrm{x}$ is said to have caused $\mathrm{y}$ when $\mathrm{y}$ would not have happened had $\mathrm{x}$ been absent.”).

59 There is some evidence that this bias exists. See Carpenter, supra note 52.

60 Morgan \& Winship, supra note 41, at 5. 
Our treatment cases are sexual assaults-those cases that we hypothesize would be affected by bias. We have to compare sexual assault cases to other comparable cases because of the fundamental problem of causal inference. Once those sexual assault cases have been treated by bias (as we assume they have), we cannot undo that treatment. In research, we cannot replay history and hold everything constant but the treatment condition. ${ }^{61}$ Once you have treated an observation and placed it into the treatment group, you can never observe how that observation would have behaved without the treatment; and when you place an observation into the control group, you cannot know how that observation would have behaved if treated. ${ }^{62}$

The best we can do is find a control group that is indeed comparable: "[W]hen experimental control and replication are not possible, analysts . . . can search for other actual cases that resemble the case in question in significant respects, except that in some of these cases [the explanatory variable] is absent (or had a different value)." 63 Our goal is to minimize the amount of difference between the two groups that is due to error, particularly error related to other omitted, lurking variables that is associated with the observed variation. ${ }^{64}$ Researchers run the following risk:

[T]he analyst adding actual cases may not know if the additional cases are appropriately identical. If there are other causes of the phenomenon in question that are not considered explicitly in the analysis, and if any of these are in fact systematically related to the causes explicitly considered, the effects of the other causes will be wrongly attributed to those of the causes that are being evaluated. ${ }^{65}$

61 See Lee Epstein \& Gary King, The Rules of Inference, 69 U. CHI. L. REV. 1, 36 (2002).

62 Morgan \& Winship, supra note 41, at 45.

63 James D. Fearon, Counterfactuals and Hypothesis Testing in Political Science, 43 WORLD POL. 169, 171 (1991) (emphasis in original) (footnote omitted); see also MAGGETTI ET AL., supra note 54, at 47-48.

64 Fearon, supra note 63, at 173-75; see also MoRGAN \& WINSHIP, supra note 41, at 1011, 88, 196-200.

65 Fearon, supra note 63, at 173-74. Bryden and Lengnick call this risk the "Equivalent Crimes Fallacy," which is "the dubious assumption that, in the absence of official bias, crimes of comparable severity will have similar rates of attrition. There is no reason to assume that the attrition rates of various crimes... ought to be equal.” Bryden \& Lengnick, supra note 23, at 1217. 
For this study, to minimize that risk, I chose control cases that only involved violence against the person. Within those control cases, I stratified the cases between very serious (murder); serious (manslaughter, robbery, aggravated assault, penetrative sexual assault); and less serious (simple assault, non-penetrative sexual assault). That scheme is shown below in Figure 1.

Figure 1: Stratification Scheme

\begin{tabular}{|c|c|c|c|}
\hline \multicolumn{4}{|l|}{ Murder } \\
\hline Manslaughter & Robbery & $\begin{array}{l}\text { Aggravated } \\
\text { Assault }\end{array}$ & $\begin{array}{l}\text { Penetrative } \\
\text { Sexual } \\
\text { Assault }\end{array}$ \\
\hline & & $\begin{array}{l}\text { Simple } \\
\text { Assault }\end{array}$ & $\begin{array}{l}\text { Non- } \\
\text { penetrative } \\
\text { Sexual assault }\end{array}$ \\
\hline
\end{tabular}

Other researchers using observational data and counterfactual reasoning have followed similar stratification techniques, although many

However, Bryden and Lengnick then use the counterfactual studies that suggest that sexual assault cases attrit at similar rates as other crimes to argue that the critics claim about bias causing attrition is wrong. Id. at 1206-07, 1212-18. They ultimately conclude that "most rape-case attrition appears to be due to a combination of the victim's unwillingness to seek legal redress, the prosecution's burden of proof in criminal cases, and jurors' attitudes.” Id. at 1384. Interestingly, they arrived at factors in sexual assault cases that critics would say are entry points for bias. The victims in sexual assault cases may withdraw from the criminal justice system because of the way they were treated; prosecutors may avoid these cases because they view it by rape myths and think the case is unwinnable; and jurors' attitudes may be influenced by rape myths. See generally Bieneck \& Krahe, supra note 30.

One factor that might affect the comparison of rape to other crimes is that the victims in sexual assault cases may be less likely to report cases that do not fit the narrative of a "real rape," where they think the probability of conviction is low, while victims of other offenses, such as assaults, may not consider the probability of conviction to the same degree. Lizotte, supra note 55, at 185. This would tend to inflate the numbers of sexual assault cases that make it through processing because only the "good" cases enter the system to start with. 
included property crimes or were not able to separate aggravated from simple assaults or penetrative from non-penetrative sexual assaults. ${ }^{66}$

One type of case that is within the control group may be too similar to the sexual assault cases, and might actually belong in the treatment group: those that involve domestic violence. Domestic violence cases may also have been treated with a similar bias. In sexual assault cases, the reasons for the bias include beliefs about how men and women should behave sexually and beliefs about how people behave in rape scenarios. In domestic violence cases, the reasons for the bias include "belief that domestic violence is a private matter, tolerance of marital violence, sexist attitudes, and a lack of confidence that victims will assist in prosecution." 67 The reasons are different but likely to be highly correlated. ${ }^{68}$ Fortunately, the data used in this study allows us to code the domestic violence cases, as discussed below, and we can exclude them from the control group.

The comparison will not be perfect and the causal inference will not be absolute: "[N]o matter how perfect the research design, no matter how much data we collect, and no matter how much time, effort, and research resources we expend, we will never be able to make causal inferences with certainty." ${ }^{69}$ But we also do not need to be perfect. By comparing only to other violent crimes against the person and then stratifying within those crimes, we can control for some outside influences and arrive at a reasonable causal inference: "[s]imply because uncertainty cannot be eliminated does not mean we cannot or should not draw causal inferences when the research necessitates it."70

\section{B. Counterfactual Studies on Sexual Assault Attrition}

Unfortunately, there is no clear answer in the counterfactual literature as to whether bias causes attrition. ${ }^{71}$ The weight of the research that has included counterfactuals is surprising-forcible rape cases do not

66 See infra note 72.

67 Felson \& Pare, supra note 35, at 436 (2007); see generally Marianne Hester, Making It Through the Criminal Justice System: Attrition and Domestic Violence, 5 Soc. PoL'Y \& SOC'Y 79 (2005).

68 See generally Michael Flood \& Bob Pease, Factors Influencing Attitudes to Violence Against Women, 10 Trauma, ViOLEnCE \& ABUSE 125 (2009); LaVerne A. Berkel et al., Gender Role Attitudes, Religion, and Spirituality as Predictors of Domestic Violence Attitudes in White College Students, 45 J. College STUDENT DEV. 119, 125 (2004).

69 Epstein \& King, supra note 61, at 36-37.

70 Id.

71 Maxwell et al., supra note 56, at 527. 
appear to have unusual attrition compared to murder, robbery, felony assault, or burglary. ${ }^{72}$

Some commentators have recognized that this counterfactual research did not support the critical claim of cause and effect. For example, Susan Estrich believed that sexism permeated law, both as

72 Mark Motivans, U.S. Dep’t of Justice, Federal Justice Statistics, 2012STATISTICAL TABLES tbl.2.2 (2015) (prosecuted in federal court: murder, 49\%; assault, 56\%; robbery, 75\%; sexual abuse, 59\%; kidnapping, 49\%); MARK MOTIVANS, U.S. DEP’T of Justice, Federal Justice Statistics, 2011—Statistical TABles tbl.2.2 (2015) (prosecuted in federal court: murder, 47\%; assault, 51\%; robbery, 73\%; sexual abuse, 60\%; kidnapping, 49\%); MARK Motivans, U.S. DEP'T OF JUSTICE, FEDERAL JustiCE StATISTICS, 2010-STATISTICAL TABLES tbl.2.2 (2013) (prosecuted in federal court: murder, 45\%; assault, 52\%; robbery, 76\%; sexual abuse, 54\%; kidnapping, $49 \%$ ); MARK Motivans, U.S. DeP’T OF Justice, Federal Justice Statistics, 2009—Statistical TABLES tbl.2.2 (2011) (prosecuted in federal court: murder, 52\%; assault, 52\%; robbery, 75\%; sexual abuse, 48\%; kidnapping, 55\%); Maxwell et al., supra note 56, at 529 tbl.1 (charge maintained after arrest: assault, 60\%; robbery, 64\%; homicide, 26\%; sexual assault, 54\%); U.S. DEP'T OF JUSTICE, COMPENDIUM OF FEDERAL JUSTICE STATISTICS, 2001, 24 (2001) (“'AA]mong violent offenses, 78\% of robbery suspects were prosecuted, while $52 \%$ of murder suspects, $44 \%$ of assault suspects, and approximately $40 \%$ of kidnaping and sexual abuse suspects were prosecuted”); CORETTA PHILLIPS \& DAVID Brown, Home Office, Entry into the Criminal Justice System: A Survey of POLICE ARRESTS AND THEIR OUTCOMES 88 tbl.6.2 (1998) (percentage of those arrested who are charged: violence against the person, $67 \%$ (likely includes murder and assaults); sexual offenses, 51\%; robbery, 48\%); Ruth Triplett \& Susan L. Miller, Case Processing in the Harris County, Texas Criminal Justice System: A Comparison Across Crime Types, 22 J. CRIM. JUST. 13, 19 tbl.3 (1994) (docketed cases resulting in conviction in year 1988: assault, 32\%; sexual assault of adult female, 34\%; sexual assault of a child, 23\%, robbery, 43\%); Steffensmeier, supra note 23, at 193, 195 tbl.1 (after the prosecutor filed charges but before the end of the merits, charges were dismissed in: rape, 22\%; homicide, 19\%; robbery, 25\%; assault, 30\%); Galvin \& Polk, supra note 23, at 135 tbl.5 (arrests filed as felonies: rape, 57\%; homicide, 77\%; robbery, 58\%; assault, 26\%; burglary, $47 \%$ ); Myers \& LaFree, supra note 23, at 1288 tbl.1 (proceeded to full prosecution: sexual assault, 82\%; other violent crimes, 81\%; property crimes, 80\%); KEITH BOTTOMLEY \& CLIVE COLEMAN, UNDERSTANDING CRIME RATES 61 tbl.4.1, 63 tbl.4.2, 96 tbl.5.1 (1981) (some categories have very few observations; for one jurisdiction in 1972, cases unfounded: violence against the person, $17 \%$; sexual offenses, $11 \%$; burglary and robbery, $6 \%$ (tbl.4.1); for the same jurisdiction, cases cleared by arrest: violence against the person, 14\%; sexual offenses, 31\%; burglary and robbery, 77\% (tbl.5.1); for another jurisdiction in 1978, cases unfounded violence against the person, 4\%; sexual offenses, 9\%; burglary and robbery, 3\% (tbl.4.2); see generally THOMAS H. COHEN \& RACEY KYCKELHAHN, U.S. DeP'T Justice, Felony DefEndANTS in LARGE URBAn COUNTIES, 2006, 10-11 (2010) (conviction rate: murder, 81\%; rape, 62\%; robbery, 71\%; assault, 54\%); Candice Minch et al., Attrition in the Processing of Rape Cases, 29 CANADIAN J. CRIMINOLOGY 389, 402 (1987); see also Loh, supra note 55, at 594-95. 
written and as applied. ${ }^{73}$ However, when discussing the impact of rape law reform on case processing (a different issue than that posed in this study), she looked at studies that had counterfactuals and found that reforms did not have much impact: any positive trends were also found in homicide, robbery, assault, and burglary offenses. ${ }^{74}$ Estrich noted that these studies were only measuring a small subset of sexual assaultsforcible, penetrative assaults often committed by strangers-and so they looked the most like "real" rape. ${ }^{75}$ In that way, these cases would likely be treated more like other "real” crimes, such as robberies and aggravated assaults, and this might mask the bias that could affect the non-stranger, "consent defense" cases. Because of that, she concluded that, "[m]any of the goals of rape law reform cannot easily be tested by statistical studies."76

The research that has found that rape attrition is similar to other crimes may not be particularly useful, though. Some of it is based on UCR data (or similar data), which has its own host of problems. Chief among these is that until 2012, the UCR used the common law definition of rape (vaginal intercourse by a man to a woman through force and without consent). Because of this, these studies only include a small category of sexual assaults - forcible, penetrative assaults - which, as Estrich noted, may be the ones that law enforcement will take most seriously. And, much of the research cannot really be interpreted because the studies do not include definitions of the applicable offenses. For example, we often do not know what the offenses of "rape" or "sexual assault" include-do they include only vaginal penetration, or oral and anal penetration; is "rape" defined under the common law, requiring force and reasonable resistance by the victim, or is it defined using modern reforms; do the sexual assaults include only penetrative assaults, or also touching offenses; was a high degree of force required, an intermediate level of force, or just the contact inherent in the penetration or touching? Some studies clearly defined the sexual offenses but then poorly define the comparison offenses, and some did not clearly define what it was they were even trying to measure.

A small amount of research reports higher attrition rates in sexual assault cases, but that research also has problems. Julian Roberts found

73 Susan Estrich, Rape, 95 YALE L.J. 1087, 1090-91 (1986).

74 Id. at 1158.

75 Id.

76 Id. at 1157; see also SUSAN CARINGELLA, ADDRESSING RAPE REFORM IN LAW AND PRACTICE 37-38 (2009) (recognizing that findings related to reform efforts, when measured against the counterfactual, are mixed). 
higher rates of attrition in sexual assault cases. For the following offenses, Roberts reports the percentage of all victim reports that did not result in a charge as: manslaughter, 28\%; simple assault, 29\%; aggravated assault, $30 \%$; aggravated sexual assault, 35\%; assault causing bodily harm, 36\%; murder, 37\%; other sexual offenses, 42\%; and sexual assault with a weapon, $46 \% .{ }^{77}$ On these numbers, Roberts concludes that "sexual assault has one of the highest attrition rates" compared to these other offenses. ${ }^{78}$

A British study ${ }^{79}$ reported that the national average, possibly for the year 2000 (the study is not clear), for all cases discontinued in the magistrates' courts is $13 \%$, while in sexual assault it is $21.6 \%$; for judge ordered acquittals, all cases is $12.8 \%$ while sexual assault is $19.2 \%$; and for judge directed acquittals, all cases is $2.4 \%$ while sexual assault is $4.8 \%{ }^{80}$ This would appear to support the critical claim; however, the comparison is to all crimes and not the category of cases that should comprise the counterfactual (other serious crimes against the person); and the entire section that is the source of the claim is five sentences long with no mention of methodology.

Some commentators have cited unreliable sources or have made improper comparisons to support claims that sexual assault cases attrit at a higher rate than other crimes. For example, Bourke cites one study to claim that 39\% of men accused of sexual assault in Britain are acquitted in magistrate's court while the average for all cases is $13 \% .{ }^{81}$ However, the study she cites only has one paragraph on counterfactuals, and the figure for rape was actually $22 \%$, not $39 \% .^{82}$ Bourke also cites another study $^{83}$ that used data from 1985 to 1997 to claim that $25 \%$ of sexual assault cases are unfounded. The study Bourke cited did not include

77 Julian V. Roberts, Sexual Assault in Canada: Recent Statistical Trends, 21 QUEEN's L.J. 395, 417-18 tbl.1 (1996).

78 Id. at 417; see also Maxwell et al., supra note 56, at 529-30 tbl.1 (2003). Maxwell and colleagues reported the following findings: the prosecutor did not reduce severity of charge in assault, 60\%; robbery, 64\%; homicide, 26\%; and sex assault, 54\%. They interpret this to mean "these results replicated past studies that found limited support for the hypothesis that sexual assault was treated more leniently compared to other violent crimes besides murder.” Id. at 534.

79 Crown Prosecution SERvice Inspectorate, A Report on the Joint Inspection INTO THE INVESTIGATION AND PROSECUTION OF CASES INVOLVING ALLEGATIONS OF RAPE 98 (2002).

80 Id. at 98 .

81 BOURKE, supra note 20, at 389.

82 Crown Prosecution Service Inspectorate, supra note 79, at 98.

83 HARRIS \& GRACE, supra note 20, at 43. 
counterfactuals, so Bourke looked to another study ${ }^{84}$ to claim that only $3 \%$ of all crimes are unfounded. That study, in turn, cited a third study ${ }^{85}$ for that figure. The third study used data from one city in 1972, where the unfounded rate for both sexual offenses and all crime was $11 \%$, and the unfounded rate for crimes of violence against the person was $17 \% ;{ }^{86}$ and the study used data from another city and county in 1978, where the unfounded rate for sexual offenses was $9 \%$, for all crimes was $4 \%$, and for violence against the person was $4 \% .{ }^{87}$ Bourke's $3 \%$ figure actually comes from a fourth study cited by this third study. That does not make for a valid comparison, and Bourke is not the only commentator or researcher to have made improper comparisons. ${ }^{88}$

Last, some of the research points to inconclusive results. A study commissioned by the U.S. Department of Justice ${ }^{89}$ for the year 1988 provides data on attrition (from the screening of cases by the prosecutor to the final outcomes) for serious offenses (murder and manslaughter, rape, robbery and aggravated assault) for ten large, urban jurisdictions, reported by jurisdiction. This study did not use the UCR and so was able to use a broader definition of rape ("forcible intercourse or sodomy with a person, including acts involving use of a foreign object") ${ }^{90}$ than that found in the UCR. Some of the data for some of the jurisdictions showed that rape had a higher rate of attrition, but for many of the jurisdictions, rape did not appear to have unusual attrition. ${ }^{91}$

84 Gregory \& Lees, supra note 11 , at 4.

85 BOTTOMLEY \& COLEMAN, supra note 72.

${ }^{86}$ Id. at 61.

${ }^{87}$ Id. at 63.

88 See JenNifer Temkin \& Barbara Krahe, SeXual Assault AND the Justice Gap: A QUESTION OF ATTITUDE 23 (2009) (claims that "in the United States, conviction rates [of rape] measured in terms of convictions as a proportion of reported offenses have been shown to be well below that of other violent crimes" and cites another study, H. Colleen Sinclair \& Lyle E. Bourne, Jr., Cycle of Blame or Just World, 22 Psychol. Women Q. 575, 576 (1998), for that proposition, but that article makes that claim without providing any support for it); Barbara Krahe \& Anja Berger, A Social-Cognitive Perspective on Attrition Rates in Sexual Assault Cases, in Social Psychology of Punishment of CRIME 335, 338 (Margit E. Oswald et al. eds., 2009) (claiming that attrition in sexual assault cases is higher than in other crimes of violence but providing citations that do not support that claim); Lea et al., supra note 12 (mis-citing Roberts, supra note 77, and PHILLIPS \& BROWN, supra note 72).

89 BOLAND ET AL., supra note 19.

90 Id. at 16.

91 See also Felson \& Pare, supra note 35, at 449, 451-52 (finding that police were more likely to make arrests for rape and sexual assault than for other physical assaults, offenders were equally likely to be convicted, and those who commit rape are more likely 


\section{Data}

The dataset for this project allows us to avoid some of the issues found with these earlier studies. The sexual assault cases in the dataset come from a jurisdiction that uses modern sexual assault definitions rather than the common law definition. ${ }^{92}$ These offenses include both penetrative and non-penetrative offenses, and the penetrative offenses include penetration of the mouth and anus. ${ }^{93}$ The comparison cases are also clearly defined, and the dataset was coded in a way that allows the cases to be stratified. ${ }^{94}$ The dataset does have several limitations, and those are discussed below.

I requested this data from the U.S. Army through a Freedom of Information Act (FOIA) request. The dataset study comes from information entered into the Army's Centralized Operations Police Suite Military Police Reporting System. The Army collects the data from two sources. The first source is the military police report, which is Department of the Army (DA) Form 3975. This record captures the initial report of the incident. Military police are supposed to record on this form all information or complaints that they receive or observe. ${ }^{95}$

After military law enforcement officers record the report of the offense on the DA Form 3975, ${ }^{96}$ law enforcement officers decide if the case is founded. A founded offense is one that is "adequately substantiated by police investigation as a violation of an [applicable law]." 97 The standard is "probable cause supported by corroborating evidence." ${ }^{98}$ Law enforcement then sends the founded investigative findings to the commander with a new form, DA Form 4833, which is the commander's report of disciplinary or administrative action. ${ }^{99}$ The commander ${ }^{100}$ then

to be incarcerated than those who commit physical assault); DeNISE LIEVORE, Prosecutorial Decisions in Adult Sexual Assault Cases: An Australian Study tbl.A.1, tbl.A.6 (2004) (reporting that sexual offenses against adults sometimes had higher conviction rates and sometimes had lower conviction rates than other crimes, and reporting that sexual assaults had higher acquittal rates than other crimes but also had higher guilty verdicts than some crimes).

${ }_{92}$ See infra Appendix.

93 Id.

${ }_{94} I d$.

95 U.S. Dep’t' of ARMy, Reg. 190-45, LAW EnForcement Reporting 9 4-2a(1) (Mar. 30, 2007) [hereinafter AR 190-45].

${ }^{96}$ Id. at $94-1(\mathrm{a})$.

${ }^{97}$ Id. at $94-3(\mathrm{a})$.

${ }^{98}$ Id.

99 Health Promotion, supra note 9, at 47-48.

${ }^{100}$ The commander is either a lieutenant colonel or higher for felony-type offenses or a 
returns the DA Form 4833 to law enforcement officials so that law enforcement can document what action was taken in the case. ${ }^{101}$ This form is the source of the data for this study.

Each case was identified by a unique case file number. The data included the following explanatory variables: year, report date, subject rank, installation, offense code, and offense description. Citing a FOIA exemption, the Army did not disclose any information about the subject so we do not have other potential explanatory variables like race, gender, or age (although age is likely to be highly correlated with rank). Army Regulation 190-45 contains an exhaustive code book for the offenses, where the first three digits describe the general offense (for example, aggravated assault). ${ }^{102}$ Sometimes a fourth digit is used to identify the weapon used or the type of victim or other details.

The data includes a categorical response variable that represents the action that the commander took in the case: no action, administrative action, nonjudicial punishment, or judicial action. The category of "no action" would include non-adverse personnel actions, like a referral to a social services agency, relief agency, or legal office. ${ }^{103}$ The category of "administrative action" includes an oral or written counseling, an oral or written reprimand, an adverse comment on an evaluation report, a relief

captain for misdemeanor-type offenses. AR 190-45, supra note 95, at \ 4-8c. In 2012, after the window for this study closed, the Secretary of Defense withheld the authority to dispose of penetrative sexual assault offenses to brigade-level commanders. Memorandum from the Sec'y of Defense on Withholding Initial Disposition Authority Under the Uniform Code of Military Justice in Certain Sexual Assault Cases to Secretaries of the Military Departments (Apr. 20, 2012) [hereinafter Sec'y of Defense Memorandum]. The Army then changed this requirement to colonels or above for those offenses. U.S. DEP'T OF ARMY, REg 195-2, CRIMINAL INVESTIGATION ACTIVITIES 9 14e(1) (July 1, 2014) [hereinafter AR 195-2].

${ }^{101}$ Health Promotion, supra note 9, at 47, 58. Army commanders are required by regulations to report all serious crimes (including sexual assaults) to law enforcement. AR 195-2, supra note 100, at $91-6$ b. Army commanders are also required to report most less serious crimes as well. U.S. DeP'T OF ARMY, REg AR 190-30, Military PoliCE INVESTIGATIONS $\uparrow 1$ 1-4c(3), tbl.4-1 (Nov. 1, 2005). Commanders are required to report all of the offenses covered by this study.

${ }^{102}$ AR 190-45, supra note 95, at tbl.4-1. This codebook was supplemented by an Army message that announced codes for the sexual assault offenses that were created in 2007 and not already in the Army regulation. All Army Activities Message, 291632Z Jun 12, U.S. Dep't of Army, subject: New Article 120 UCMJ Offense Codes. While this message post-dates the 2007 changes, the dataset contained these codes, and it was obvious that they were in use during this period.

${ }^{103}$ U.S. Dep't of Army, DA Form 4833, Commander's Report of Disciplinary or Administrative Action (June 2004) [hereinafter DA Form 4833]. 
for cause from a duty position, a suspended security clearance, or an administrative discharge. ${ }^{104}$ The category of "nonjudicial punishment" refers to a summarized, punitive process where the subject has a limited hearing before a commanding officer who determines guilt and punishment. The potential punishments are based on the subject's rank, but generally amount to small fines, reductions in rank, extra-duty and restrictions for up to 45 days, or a combination of those. ${ }^{105}$ The final category is "judicial," which includes referral to a summary, special, or general court-martial. This category also includes instances where a civilian criminal justice system processed the offense instead of the military justice system. ${ }^{106}$ More than one action could have been taken in a particular case.

While judicial action is clearly a more serious disposition than nonjudicial punishment, administrative action, or no action, it is difficult to say that nonjudicial punishment is a more serious disposition than administrative action. Some administrative actions-being separated from the service-are quite serious, while some nonjudicial punishments (summarized Article 15s, for example) are not that serious. For that reason, I treated this variable as a nominal ${ }^{107}$ rather than ordinal ${ }^{108}$ variable.

For the first two categories, we can assume that the non-adverse personnel action or the administrative action was actually imposed. For the nonjudicial punishment and judicial punishment, we know that the commander sent the subject to those proceedings but we do not know the results of the proceedings. In both, the charges could have been later dismissed or the subject could have been acquitted. ${ }^{109}$

A few comments about the data are needed. First, only founded reports are included in this data but the decision to unfound the case may itself be biased. Again, the definition of founded is "adequately

\footnotetext{
${ }^{104}$ Id.

10510 U.S.C.A. $§ 815$ (2012); MANUAL FOR COURTS-Martial, United States pt. V (2012) [hereinafter MCM].

${ }^{106}$ DA Form 4833, supra note 103.

${ }^{107}$ Nominal variables are categorical variables that do not have a high or low end, such as a transportation variable that includes "automobile, bus, subway, bicycle, walk.” ALAN AGRESTI \& BARbARA Finlay, STATISTICAL METHODS FOR THE SOCIAL SCIENCES 12 (4th ed. 2009).

${ }^{108}$ Ordinal variables are categorical variables that have a natural ordering of variables from low to high. Id. at 12-13.

${ }^{109}$ Later sections of the form include this information, but that point of attrition is beyond the scope of this research question.
} 
substantiated by police investigation as a violation of an [applicable law]," 110 where the standard is "probable cause supported by corroborating evidence." 111 If the investigating officer is not trained on how to spot corroborating evidence in a one-on-one witness case, then to that officer, the case could be unfounded. If the officer does not believe the victim because the officer is using schemas to assess credibility that are based on rape myths, then to that officer, the case could be unfounded. Further, the investigating officer may not be trained on how to interview a sexual assault victim, and may actually alienate the victim by using aggressive interviewing techniques based on the Reid technique, normally used to interrogate suspects of a crime. When the victim then drops out of the case, to that officer, the case could be unfounded. ${ }^{112}$

Law enforcement would not forward those cases to the commander and so those cases would not make this dataset. ${ }^{113}$ If there is bias in the system, it may have already had its effect. The cases that do not fit the generalized image of what a rape case should look like would be filtered out early, so that the only cases that do reach the commander do fit that image and so are easier to take action on.

Second, this data only includes military offenders. Commanders can only take action on members of their command and not civilians (with some minor exceptions). Furthermore, this data only includes offenders within the command that have been identified. Commanders can only take

\footnotetext{
${ }^{110}$ AR 190-45, supra note 95, at 105.

${ }^{111} \mathrm{Id}$.

112 The UCR database is subject to the same issue. See RoBERT M. REgOLI ET AL., EXPLORING CRIMINAL JuSTICE 58-59 (2d ed. 2013); CASSIA SPOHN \& KATHARINE TELLIS, Policing \& Prosecuting SeXual Assault 24-27, 120-22 (2014).

113 The process of sending cases from law enforcement to commanders began to change in 2012, following the period of this study. In 2012, the Secretary of Defense withheld the authority to take no action on a sexual assault case from special court-martial convening authorities that are in the grade of 0-6. Sec'y of Defense Memorandum, supra note 100. Congress then required the Secretary of Defense to amend how law enforcement forwarded files to commanders to include looking at whether law enforcement should include a recommendation on whether the offense was founded or unfounded. National Defense Authorization Act for Fiscal Year 2014, Pub. L. No. 11366, § 1732, 127 Stat. 975-76. In response, the Department of Defense directed that at the conclusion of an investigation, law enforcement should not report investigative conclusions, like whether the offense was founded or unfounded, in the investigative reports. U.S. DEP'T OF DEF., INSTR. 5505.03, INITIATION OF INVESTIGATIONS BY DEFENSE CRiminal InVESTigative ORGANizATIONS encl. 2, ๆ 7.a. (Dec. 22, 2015). Now, all of these reports should make it to a commander.
} 
action against known, identified offenders. ${ }^{114}$

Third, when processing this data, the Army follows a hierarchy rule similar to the one used by the FBI in the UCR Program. ${ }^{115}$ If an incident involves multiple offenses, only the most serious offense from that incident shows up in the reported data. The other offenses are listed below that code in the appropriate block or on a supplementary form. ${ }^{116}$ Because of this, some offenses might not be captured in this database if another, more serious offense also occurred. For example, if a victim was robbed and assaulted, only the robbery would make its way into this study.

One important exception to this rule is that if the case involves domestic violence, military law enforcement enters the case twice: first, under the code for the primary offense, and second, with a special code to indicate that the case involves domestic violence. ${ }^{117}$ This allows us to identify another potential category of cases which may have been treated with gender bias - those involving domestic violence.

Fourth, the data only includes unrestricted reports. The Department of Defense (and the Army) allows for restricted reports, where the victim can choose to make a report that allows access to victim services but where the report will not be transmitted to law enforcement or to the chain of command. ${ }^{118}$ By definition, restricted sexual violence or domestic assaults reports will not make the military police report, the DA Form 4833, or this dataset. ${ }^{119}$

Fifth, under the Army's coding system, attempted and completed offenses use the same offense code ${ }^{120}$ unless a specific attempt code is in

\footnotetext{
${ }^{114}$ AR 190-45, supra note 95, at 9 4-8a(1).

115 UCR HANDBOOK, supra note 15, at 10.

116 AR 190-45, supra note 95, at app. B, ๆ B-2c.

${ }^{117}$ AR 190-45, supra note 95, at 9 4-17b. This causes a lot of duplicates in the data. For my treatment of these duplicates, see infra Appendix.

118 U.S. Dep'T OF Def., Instr. 6495.02, Sexual Assault Prevention AND Response (SAPR) Program PROCEDUReS (July 7, 2015) 121 (defining "restricted report") [hereinafter AFI 6495.02]; U.S. DEP’T OF ARMY, REg. 600-20, ARMY COMMAND POLICY I 8-4 (Nov. 6 2014). Survivors of domestic violence can also use restricted reports. U.S. DeP'T OF DeF., INSTR. 6400.06, DOMEstic Abuse InVOlving DoD MilitaRy AND Certain Affiliated Personnel 4 (Aug. 21, 2007); AR 190-45, supra note 95, at 9 416.

119 To provide some scale, in fiscal year 2014, survivors made 4,660 unrestricted reports and 1,840 restricted reports of sexual assault. Later, 369 of the survivors who initially filed restricted reports changed them to unrestricted reports. DOD ANNUAL REPORT, supra note 21 , at 7 .

${ }^{120}$ AR 190-45, supra note 95, at 9 B-2c(5).
} 
the codebook. ${ }^{121}$

Last, the data is subject to two types of error. First, the system is decentralized and the accuracy of each individual offense code is dependent on the particular law enforcement officer who input the data. The official Army code book is detailed, but it is also long and has some areas that overlap and where the law enforcement officer may have to choose between different codes. In this study, I will only be using the first three digits of the code, which is the code for the primary offense. Those offenses are pretty general (again, something like aggravated assault) and if there were an error, it would be more likely to be in the fourth digit of the code (if the fourth digit is used) than in the primary offense code. Since I am not using that fourth digit, this potential error is not likely to significantly impact this study.

As a second source of error, during the period covered by this study, the Army was having a general problem with commanders not returning the DA Form 4833s. Commanders only returned about two in three. ${ }^{122}$ The Army report that discussed this problem did not include a breakdown of which offenses, if any, were under-returned. ${ }^{123}$ I think it is safe to assume that commanders would be most likely to return the reports on more serious offenses (like homicides, robberies, aggravated assaults, and penetrative sexual assaults), more likely to return the reports on serious offenses like simple assaults and non-penetrative sexual assaults, and probably least likely to return reports on less serious offenses, like minor thefts or drug use. If that assumption is true, then the commanders' non-response rate is not likely to impact this study.

\section{Hypothesis}

My hypothesis is that commanders do not treat sexual assault cases more leniently than other similar crimes of violence against the person. While there may be bias, that bias would not have a causal effect

\footnotetext{
${ }^{121}$ Generally, the attempt offense (sometimes listed in the codebook as another offense committed with the intent to commit the greater offense) is identified using the fourth digit of the primary three-digit code for the greater offense, so these are easily counted as the primary offense by dropping the fourth digit. For example, penetrative sexual assault is coded 6E1 while assault with attempt to rape is coded 6E1A. I made an omission in my FOIA request in that I did not request data for burglaries. Assault with attempt to commit burglary and assault with intent to commit housebreaking are coded as burglary offenses, so those two types of assaults (if the law enforcement officer chose that code instead of a standard assault code) will not be in this dataset.

122 HeAlth Promotion, supra note 9, at 61.

${ }^{123}$ Id.
} 
at this stage of attrition.

I arrived at this hypothesis because the weight of the research in this area suggests that sexual assault cases do not have unusual attrition problems. ${ }^{124}$ Further, because the dataset only included founded cases, I expected that bias would have an effect, if any, at the founding stage of attrition. The cases that reached the commanders would have already been filtered. ${ }^{125}$

One could argue that the previous research in this area will not fully apply to the military because, at least during the period of this study, the military allowed evidence of an accused's good military character to be considered when processing ${ }^{126}$ and adjudicating ${ }^{127}$ the case. Part of the basic theory is that commanders have trouble believing that good soldiers can be rapists, and this evidence plays into that belief. This would then cause higher rates of attrition. However, law enforcement officers would also be looking for that evidence, so that bias would still likely have an effect at an earlier attrition stage.

One could also argue that commanders took these cases more seriously than other cases because of the attention Congress recently has given to the military's sexual assault problems. The argument is that commanders are afraid of the political consequences of not referring a case. Commanders realize that Congress votes on their confirmations to higher ranks and so, if the commanders are risk-averse, they would send every case they get forward to trial. ${ }^{128}$ This concern is essentially the opposite of the downstream orientation described by Lisa Frohmann, where risk-averse prosecutors might not send a case to trial because they

${ }^{124}$ See supra note 72 , at 91.

125 See generally Corey Rayburn Yung, How to Lie with Rape Statistics: America's Hidden Rape Crisis, 99 IowA L.R. 1197 (2014); Cassia Spohn \& Katharine Tellis, Justice Denied? The Exceptional Clearance of Rape Cases in Los Angeles, 74 ALB. L.R. 1379 (2010).

126 MCM, supra note 105, R.C.M. 306(b) discussion. Congress directed the President to delete the relevant language from that discussion. National Defense Authorization Act for Fiscal Year 2014, Pub. L. No. 113-66, § 1708, 127 Stat. 961. The President complied. Exec. Order No. 13669, Fed. Reg. 34,999 (June 18, 2014).

127 See generally Elizabeth Lutes Hillman, The "Good Soldier" Defense: Character Evidence and Military Rank at Courts-Martial, 108 YALE L.J. 879 (1999). Congress directed the President to severely limit this rule. National Defense Authorization Act for Fiscal Year 2014, Pub. L. No. 113-66, § 536, 127 Stat. 672. The President complied. Exec. Order No. 13696, 80 Fed. Reg. 35,783 (June 22, 2015).

${ }^{128}$ See Helene Cooper, A Question of Military Justice in Sexual-Assault Trials, SEATTLE TIMES (Mar. 22, 2014, 8:07 PM), http://www.seattletimes.com/nation-world/a-questionof-military-justice-in-sexual-assault-trials/. 
are afraid of the political consequences of losing the case. ${ }^{129}$ Here, the argument is that commanders are afraid of the downstream consequences to their careers of not referring a case.

This would be an explicit, conscious use of bias by a senior commander, favoring his self-interests over the interests of a junior soldier. While some commanders might do that, I expect that those commanders would be outliers and most commanders would consciously reject this bias. To hold otherwise is to have a fairly cynical view of military commanders. The outliers should not affect the trends in attrition data. Instead, I expect that implicit bias would manifest as trends in attrition data-although I do not expect to see those trends at this attrition point.

\section{FINDINGS}

The findings partially support my hypothesis. The disposition of cases by total number of cases and percentage of cases within category are reported in Table 1.

Table 1: Disposition by Category of Cases (Total Cases and Percentage) $\mathrm{n}=17,424$

1. Murder

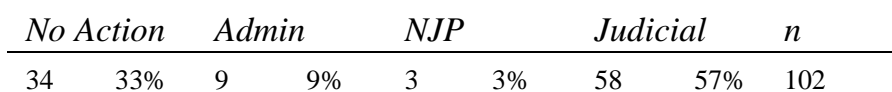

2. Manslaughter

$\begin{array}{lllllllll}17 & 52 \% & 2 & 6 \% & 3 & 9 \% & 11 & 33 \% & 33\end{array}$

3. Robbery

$18 \quad 20 \% \quad 23 \quad 25 \% \quad 7 \quad 5 \% \quad 56 \quad 62 \% \quad 91$

4. Aggravated $453 \quad 25 \% \quad 555 \quad 30 \% \quad 415 \quad 23 \% \quad 652 \quad 36 \% \quad 1,830$ Assault

5. Penetrative 55 Sexual Assault

6. Simple Assault $\quad 3,943 \quad 26 \% \quad 5,889 \quad 39 \% \quad 2,998 \quad 20 \% \quad 3,955 \quad 26 \% \quad 15,001$

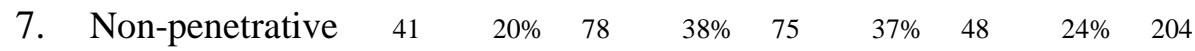
Sexual Assault

Note: The sum of the row totals may exceed the total cases because more than one action may have been taken in a case.

${ }^{129}$ See Frohmann, Convictability and Discordant Locales: Reproducing Race, Class, and Gender Ideologies in Prosecutorial Decisionmaking, supra note 34, at 535-37. 
Figure 2: Disposition of Cases by Category

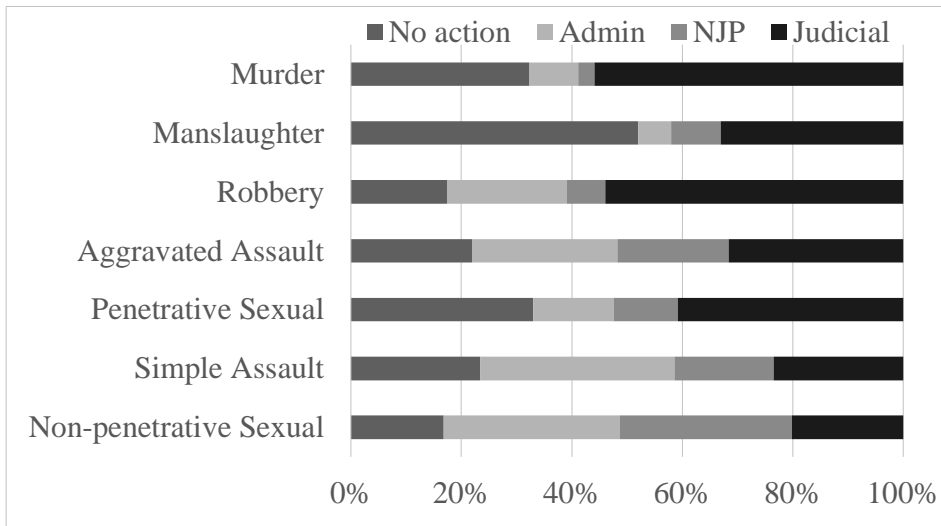

Sexual assault cases do not appear to be obvious outliers. Commanders take no action in penetrative sexual assaults more frequently than in other cases. However, commanders take judicial action in those cases more frequently than in assault cases, and at about the same frequency as manslaughter cases.

Commanders appear to take non-penetrative sexual assaults more seriously than they do other simple assaults. They take no action in fewer cases, judicial action in about the same amount of cases, and use nonjudicial punishment in more cases.

I calculated odds ratios using two-by-two contingency tables, where one variable was the category of cases (penetrative sexual assaults versus the control cases) and the other variable was one of the four disposition outcomes. ${ }^{130}$ I report those in Table 2.

Table 2: Comparison of Odds Ratios, Penetrative Sexual Assault and Control Cases

\begin{tabular}{lrl}
\hline & Penetrative SA & \\
\hline No action & $58 \%$ & Control \\
Admin & & $<139 \%$ \\
NJP & $<100 \%$ \\
Judicial & $22 \%>$
\end{tabular}

The odds that commanders would take no action in penetrative

\footnotetext{
130 I also calculated the odds ratios excluding robbery and manslaughter. Because there were only a few of those cases, the results were essentially the same.
} 
sexual assault cases were $58 \%$ greater than the odds for the control cases. Compared to the penetrative sexual assault cases, the odds that commanders would take administrative action in the control cases were $139 \%$ greater and the odds that the commanders would take nonjudicial punishment action in the control cases were $100 \%$ greater. But, the odds that commanders would take judicial action in penetrative sexual assault cases were $22 \%$ greater than the odds in the control cases.

For penetrative sexual assaults, it appears that commanders take more of an all-or-nothing approach than they do with other cases. Fewer cases may go forward, but the cases that do go forward are treated more seriously. It appears that if commanders believe that an offense happened, then they are more likely to take the most serious type of action in that case and are less likely to use alternatives like administrative action or nonjudicial punishment. However, it also appears that commanders are more likely to take no action in these cases. That is consistent with the theory that commanders have an implicit bias in these cases and that bias has a causal effect on attrition.

For non-penetrative sexual assaults, the story appears to be somewhat different. Across the board, commanders appear to take these cases as seriously or more seriously than simple assaults.

Table 3: Comparison of Odds Ratios, Non-penetrative Sexual Assault and Control Cases

\begin{tabular}{lrll}
\hline & Non-penetrative SA & & Control \\
\hline No action & & $<40 \%$ \\
Admin & $5 \%$ & \\
NJP & $136 \%$ & $>$ \\
Judicial & & $<9 \%$
\end{tabular}

The odds that commanders would take no action in simple assault cases were $40 \%$ greater than the odds in the non-penetrative sexual assault cases. The odds that commanders would take administrative action were essentially the same for both (5\% greater for non-penetrative sexual assaults). The odds that commanders would take nonjudicial action in non-penetrative sexual assault cases were $136 \%$ greater than the odds for simple assaults. Lastly, the odds that commanders would take judicial action were essentially the same (9\% greater for simple assaults).

Looking at the domestic violence cases, nearly all were aggravated or simple assaults. There was one each in murder and robbery, and seven each in penetrative sexual assaults and non-penetrative sexual 
assaults. I left those observations in those categories.

Table 4: Disposition by Category of Cases (Total Cases and Percentage), Domestic Violence as Separate Category $\mathrm{n}=17,424$

1. Murder

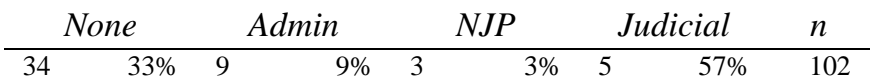

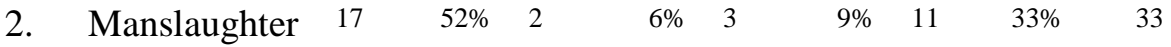

$\begin{array}{lllllllllll}\text { 3. } & \text { Robbery } & 18 & 20 \% & 23 & 25 \% & 7 & 8 \% & 56 & 62 \% & 91\end{array}$

4. Aggravated $\quad 360 \quad 25 \% \quad 441 \quad 30 \% \quad 354 \quad 24 \% \quad 505 \quad 34 \% \quad 1,463$ Assault

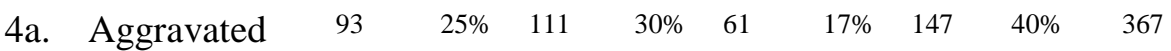
Assault DV

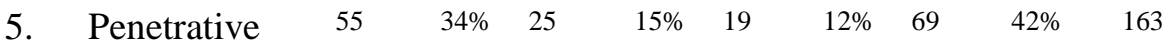
Sexual

6. Simple

$2,396 \quad 27 \% \quad 3,426 \quad 39 \% \quad 2,263 \quad 26 \% \quad 1,936 \quad 22 \% \quad 8,725$

Assault

6a. Simple

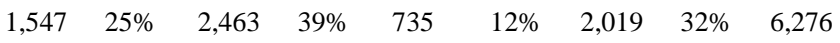
Assault DV

7. Non$\begin{array}{lllllllll}41 & 20 \% & 78 & 38 \% & 75 & 37 \% & 48 & 24 \% & 204\end{array}$ penetrative Sexual

The sum of the column totals may exceed the total cases because more than one action may have been taken in a case. 
Figure 3: Disposition of Cases by Category, Domestic Violence as Separate Category

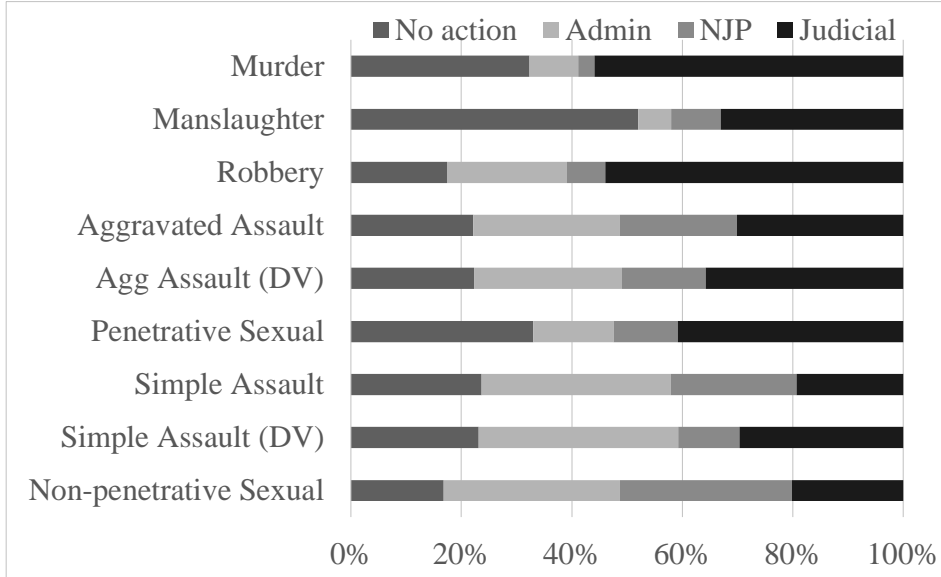

I recalculated the odds ratios using two-by-two contingency tables, where one variable was the category of cases (penetrative sexual assaults) versus the control cases (manslaughter, robbery, and aggravated assaults) but with the domestic violence cases removed. The odds ratios were essentially the same for all of the comparisons across penetrative sexual assaults and the control cases, and the non-penetrative sexual assaults and the control cases. One difference was in the non-penetrative sexual assaults. When domestic violence was included in the control group, the odds that commanders would take nonjudicial punishment action was $136 \%$ greater than the odds for the control cases. When domestic violence cases were excluded from the control group, the odds ratio reduced from $136 \%$ to $69 \%$.

An interesting secondary finding is that commanders treat domestic violence cases, both aggravated and simple, more seriously than comparable crimes.

Table 5: Comparison of Odds Ratios, Aggravated Domestic Assault and Aggravated Non-domestic Assault Cases

\begin{tabular}{lrrr}
\hline & $\begin{array}{r}\text { Aggravated Domestic } \\
\text { Assault }\end{array}$ & $\begin{array}{c}\text { Aggravated Non- } \\
\text { Domestic Assault }\end{array}$ \\
\hline No action & & \\
Admin & $=$ & \\
NJP & $60 \%$ & $>$ \\
Judicial & $29 \%$ & $>$
\end{tabular}


For aggravated assault cases, the odds that commanders would take no action or administrative action were the same between those cases involving domestic violence and those not involving domestic violence. But the odds that commanders would take nonjudicial punishment action were $60 \%$ greater in cases involving domestic violence, and the odds that commanders would take judicial action was $29 \%$ greater.

Commanders took the simple domestic violence cases even more seriously.

Table 6: Comparison of Odds Ratios, Simple Domestic Assault and Simple Non-domestic Assault Cases

\begin{tabular}{lrll}
\hline & Simple Dom Asslt & & Simple Non-dom Asslt \\
\hline No action & & $<$ \\
Admin & & $12 \%$ \\
NJP & $150 \%$ & $>$ \\
Judicial & $68 \%$ & $>$
\end{tabular}

The odds that commanders would take administrative action were the same between those cases that involved domestic violence and those that did not. But the odds that commanders would take no action in a case without domestic violence were $12 \%$ higher than the odds in a domestic violence case. The odds that commanders would take nonjudicial punishment action in a domestic violence aggravated assault case were $150 \%$ greater. And the odds that commanders would take judicial action were $68 \%$ greater than the odds in simple assault cases without domestic violence.

The treatment of domestic violence cases is consistent with how commanders treat non-penetrative sexual assaults and consistent with how commanders treat penetrative sexual assaults, once commanders decide to take action on those cases.

\section{Discussion AND CONCLUSION}

The hypothesis was that commanders do not treat sexual assault cases more leniently than other similar crimes of violence against the person. If the data had suggested that commanders treated the cases the same, this could have meant one of two things: either there is bias but the bias did not have a causal effect (which is the position I endorsed), or there is no bias at all.

The data generally supports this broader hypothesis. Commanders take non-penetrative sexual assaults as seriously as or more seriously than other similar cases. Commanders also take penetrative assaults more 
seriously than other similar crimes, if they decide to take action on a case. The data suggests that either there is no bias against sexual assault victims, or if there is, the bias does not cause attrition.

As a surprising secondary finding, commanders take domestic violence cases more seriously than other similar assaults. This suggests that there is no bias against domestic violence victims, or if there is, the bias does not cause attrition in that class of cases. As discussed above, the belief systems that would lead to bias in domestic violence and sexual assault cases are similar. If bias existed in one category of cases, we should expect to find it in both. Instead, we find it in neither.

As discussed above, one might not find bias at this attrition point because it has already had its effect at an earlier attrition point-when law enforcement founds or unfounds a case. If law enforcement officials are influenced by implicit bias, they may not fully develop the facts in cases that otherwise have merit, or might conduct adversarial interviews with victims that alienate victims from the process. They may then unfound these cases, and during the period of this study, those cases would not make it to the commanders. Only the "good" cases would.

Certainly, current reform efforts should focus on this earlier stage in the attrition process, and Congress, the President, and the Secretary of Defense have focused attention on law enforcement. "Good soldier" evidence - the kind that feeds bias for the offender-is no longer relevant to the case. ${ }^{131}$ The case forwarding process has changed, so that now, law enforcement sends the file to the commander without including a "founding" determination. ${ }^{132}$ Training requirements have increased and focus on recognizing offender behaviors. Training has also focused on understanding victims, to include understanding victim responses to trauma and the impact of trauma on memory and recall, which should lead to better victim questioning techniques. ${ }^{133}$

Once certain that bias does not exist at that attrition point, then we should revisit whether commanders are biased when processing the new, more robust set of cases that will come across their desks. If those earlier reforms work, though, this larger set of cases should be fundamentally different than before. This will not just be a set of cases with the same number of "good" cases as before, but with a bunch of extra "bad" cases

${ }^{131}$ See generally Hillman, The “Good Soldier" Defense, supra note 127; see also National Defense Authorization Act for Fiscal Year 2014, Pub. L. No. 113-66, § 1708, supra note 126, at 127 Stat. 961.

132 See U.S. DEP’T OF DEF., INSTR. 5505.03, supra note 113, at 9 7.a.

${ }^{133}$ AFI 6495.02, supra note 118, at encl. 10, ๆ 7.a, e, f. 
added in. Rather, what would have earlier been viewed as a bad case will have been properly investigated and developed —and will look like a good case, probably even to a commander who may endorse some rape myths.

Still, there is a significant inconsistency with the hypothesis. Commanders do not take action in penetrative sexual assault cases more frequently than in other similar cases. Counterfactual reasoning suggests that bias causes this attrition. This may indicate that when the seriousness of the offense goes up-as the stakes rise for the offender, both with increased stigma and formal penalties_commanders become more risk averse.

They may slow down and think carefully about that case. This would generally mean that that they would move away from unconscious decision making (relying on heuristics, called System 1 processing) to more conscious, controlled, systematic decision making (called System 2 processing). ${ }^{134}$ While we should expect that implicit bias would be reduced with this conscious, controlled, systematic decision making, this decision making may still be plagued by implicit bias.

As commanders slow down to think hard about these cases, they are still operating in an environment of limited information. The commanders did not see the sexual assault. They have to rely on written statements made by people they do not know. When information is limited, "complex cognitive strategies are of very limited usefulness."135 Commanders have to rely on circumstantial evidence to decide if the victim is telling the truth (that he or she did not consent) or if the offender is telling the truth (that the alleged victim did consent, or at least, the offender thought he had consent). That circumstantial evidence requires the commanders to make an inference, and that inference requires them to apply their own life rules and generalizations about how people behave.

If those life rules and generalizations are themselves inaccurate (as in, rape myths), then a conscious, controlled, systematic decisionmaking process will only give the commanders a more careful application of facts to incorrect generalizations. This allows bias to enter the process, and results in higher rates of attrition.

The key is to train commanders on the realities of sexual assault so that when they do slow down with these very serious cases, they do not

\footnotetext{
${ }^{134}$ See Susan T. Fiske, Social Beings: Core Motives in Social Psychology 258-61 (3d ed. 2014); MichaEL W. EysencK \& MARK T. KeANE, Cognitive PsyChOlOGy 51113 (6th ed. 2010).

135 EYSENCK \& KEANE, supra note 134, at 511.
} 
apply inaccurate generalizations when solving these problems. Training requirements for commanders have increased significantly since the period of this study, and current training focuses on rape myths. ${ }^{136}$

The public policy implication is that, at least for now, Congress does not need to remove commanders from the system. This training, coupled with improved law enforcement procedures-and given time to work - may lead to a reduction in attrition at this point.

The military was once under scrutiny for its handling of domestic violence cases and responded to that criticism with changes in policy and by resourcing programs to address domestic violence. The data from this study suggests that those responses, once put in place and given time to work, did work. Commanders now take those cases more seriously than their counterparts. That result may also occur in the sexual assault context. After the responses to the sexual assault problem are given time to work, we may see sexual assault cases treated more seriously than comparable crimes.

\section{APPENDIX}

\section{A. Data Screening and Reduction}

The original dataset had 54,212 observations. No cells had missing data. No outliers were found in the "Action Taken, Administrative, Nonjudicial, Judicial” column. Observations that were marked as "pending” or "missing” were deleted.

I then searched the data observations that did not fit the project. To remove child victims, I sorted by offense codes and deleted the observations that were coded for child offenses (5C2C, 5D1, 5D2, 5D7A, 5D7B, 6A, 6C5, 6E1B, 6E2, 6E3B). I searched for child offenses by searching for the terms, "child" "under 18" "under 16" "under 12" "minor" "youth" "age" and deleted entries where the offense description column made it appear that the victim was a child. I deleted observations that were coded for family abuse (5D7, 5D9) because I could not determine if there was an assault or who the victims were. I deleted observations coded for indecent acts $(6 \mathrm{C} 2-4,9)$ because those could include consensual acts. I deleted observations coded for sodomy (6F1AB) because those appeared to be consensual sodomy as contrasted to forcible sodomy (6F1). I also deleted observations that did not appear to involve actual or attempted violence to the person: I deleted observations

${ }^{136}$ AFI 6495.02, supra note 118, at encl. 10, ๆ 3.g(2). 
coded for violation of protective orders (5D3), and I searched for the terms "reckless endangerment" "harassment" and "stalking" and deleted observations that did not appear to involve actual or attempted violence directed toward a specific person. I searched for "property" and removed observations that were clearly crimes against property. I searched for "unfounded" and "insufficient" to remove observations that may have later been determined to be unfounded and which should not have been in the dataset and deleted those observations. Several observations that were coded as 5C5 were not for maiming but were for driving while intoxicated, and I removed those.

There were multiple duplicate entries for unique observation numbers (just over half of the observations had a duplicate). The observation numbers represented the case file number. When law enforcement updated the database, the system would generate another observation under the same case file number. When law enforcement entered a supplemental report, the case observation number would end in a " -1 ". The most common reason for a duplicate entry was a change in the subject's rank. In addition, some observation numbers were duplicates because the same observation number had been assigned different offense codes, particularly the domestic violence codes.

I deleted exact duplicates. I then developed the following rulebook for my research assistants to use when deleting and consolidating duplicate observations. The basic rules were to retain as much data as possible and when data conflicted, to choose the highest value of the data. I trained the research assistants on the rulebook and we went over several deletion decisions together as a group. Occasionally, the offense description did not match the code description, most often when a civilian criminal code was cited. When making some deletion decisions, we used the offense description to clarify the severity or type of offense, and sometimes had to recode the observation to match the appropriate code.

\begin{tabular}{|l|l|}
\hline "Rank" duplicates & $\begin{array}{l}\text { Keep the observation with the highest rank, } \\
\text { and if no other differences, delete the others. }\end{array}$ \\
\hline “Action taken" & $\begin{array}{l}\text { If one duplicate shows an action taken in one } \\
\text { column and the other duplicate shows an } \\
\text { action taken in a different column (with no } \\
\text { overlap), consolidate all of the actions taken } \\
\text { into one observation, and if there are no other } \\
\text { differences, delete the others. }\end{array}$ \\
\hline
\end{tabular}




\begin{tabular}{|l|l|}
\hline & $\begin{array}{l}\text { If one duplicate shows an action taken in one } \\
\text { column and the other duplicate shows no } \\
\text { action taken in any column, keep the action } \\
\text { taken in one observation, and if there are no } \\
\text { other differences, delete the others. }\end{array}$ \\
\cline { 2 - 3 } & $\begin{array}{l}\text { Before you delete a duplicate observation, } \\
\text { consolidate any "action taken" in the } \\
\text { observation that you will keep. }\end{array}$ \\
\hline "Code” duplicates & $\begin{array}{l}\text { If the duplicate has multiple observations, } \\
\text { keep the most serious code. }\end{array}$ \\
\cline { 2 - 3 } & $\begin{array}{l}\text { If the duplicates are in the same crime } \\
\text { category (first three digits of the code) and it } \\
\text { is unclear which is more serious, retain either } \\
\text { one. }\end{array}$ \\
\cline { 2 - 2 } & $\begin{array}{l}\text { If the duplicates included multiple types of } \\
\text { assault, keep the aggravated assault (5C1) and } \\
\text { delete the simple assault (5C2, 5C3). }\end{array}$ \\
\cline { 2 - 2 } & $\begin{array}{l}\text { If there are multiple simple assaults, keep the } \\
\text { assaults with special victims (5C3) over other } \\
\text { simple assaults (5C2). }\end{array}$ \\
\hline $\begin{array}{l}\text { If the duplicates include an inchoate offense } \\
\text { (attempt, solicitation, conspiracy) and a } \\
\text { completed offense, keep the one from the } \\
\text { most serious category; if within the same } \\
\text { category, keep the completed offense and } \\
\text { delete the inchoate offense. }\end{array}$ \\
\hline
\end{tabular}

137 This is consistent with the Army's reporting rules. AR 190-45, supra note 95, at app. B, I B-2c(1), (6). The Army does not provide a hierarchy of offenses, so I turned to the Uniform Crime Reports for Guidance. The Uniform Crime Reports Handbook creates a hierarchy of offenses, ranking as follows: homicide $>$ forcible rape > robbery $>$ aggravated assault. When resolving duplicates, I followed that ranking, but included all sexual assaults (penetrative and non-penetrative) under sexual assaults, and all assaults (aggravated and simple) under assaults. One could argue that robberies or aggravated assaults are more serious than non-penetrative sexual assaults; in any event, within this dataset, that hierarchy conflict was very rare. I included also indecent assaults (6C1, which are non-penetrative sexual assaults) and forcible sodomy (6F8) in sexual assaults, and maiming (5C5) in assaults. 


\begin{tabular}{|l|l|}
\hline & $\begin{array}{l}\text { If one of the duplicates had a domestic } \\
\text { violence code, keep the primary assault } \\
\text { offense; put the domestic violence code in } \\
\text { another column and the domestic violence } \\
\text { offense description in third column. } \\
\text { Consolidate any action taken for the domestic } \\
\text { violence observation with the primary offense } \\
\text { observation. }\end{array}$ \\
\hline
\end{tabular}

Following the completion of the duplicate deletion project, I trained a new research assistant on the task and provided the new research assistant with the rulebook and gave her $10 \%$ of the duplicates, selected by breaking the duplicates (roughly 24,000 observations) into 100-count blocks and randomly selecting 24 blocks. If the first or last observation in the block was a duplicate with an observation in a previous or subsequent block, all of the duplicate observations were assigned to that block. I then compared those results to the initial screeners' results. The error rate (meaning, the resulting observations were reduced differently) was very low, at .03\%.

When I made my initial FOIA request, I failed to ask specifically for manslaughter and negligent homicide cases so I submitted a second FOIA request for that data. I screened this data and deleted duplicates as above. In addition, this dataset included observations on civilian subjects. I deleted those subjects (commanders do not have jurisdiction over civilian subjects). This dataset included observations that appeared to have been unfounded at the law enforcement level, and I deleted those. There was one difference between this dataset and the other dataset. The primary dataset included a column for each action taken, and for a few observations, there may have been more than one action taken. The secondary dataset only included one column for "action taken" and listed one action taken, so if one observation had multiple actions taken, that would not be reflected in the data. Rather than lose some fidelity in the larger dataset by reducing the "action taken" to just the most serious action taken, I consolidated the two datasets by listing just the action taken in the secondary dataset (fewer than 120 observations.) When analyzing the manslaughter and negligent homicide offenses, we need to keep that in mind.

Roughly 2,300 observations were only coded for the domestic violence offense and did not include a primary offense. I searched these observations for the terms "aggravated," "great," "grievous," and "weapon" and coded those observations as aggravated assaults (5C1). I 
coded the rest as simple assaults (5C2). I also searched the observations that had not been coded as domestic violence offenses with the terms "domestic," "spouse," and "DV" and coded those as domestic violence observations.

I then reduced the dataset to observations from the years 2008-11 because the sexual assault laws were changed significantly in 2007 and changed somewhat again in 2012, and I wanted to limit this study to one potential treatment condition.

\section{B. Explanation of Crime Categories}

\section{Penetrative and Non-penetrative Sexual Assaults}

During the period of this study, the military used a sexual assault statute that was roughly based on the Michigan model. ${ }^{138}$ Under this model, consent is not written in as an explicit element of the offense; rather, the statute focuses on the level of force the offender used and the type of sexual action the offender committed.

The military's sexual assault scheme during the period of this study had three penetrative offenses: rape, aggravated sexual assault, and forcible sodomy. ${ }^{139}$ Consistent with the Michigan model, the difference between rape and aggravated sexual assault is the level of force the offender uses to cause the sexual activity. Rape involves a high degree of force and aggravated sexual assault involves a lower degree of force. For both, the required sexual activity is contact of the penis and the vulva, or penetration of the genital opening by a hand, finger, or other object with the intent to abuse, humiliate, harass, or degrade any person, or to arouse the sexual desires of the offender. ${ }^{140}$ The required sexual act did not include contact of the penis to the victim's mouth or anus; however, penetration of the mouth or anus fell within the forcible sodomy statute. ${ }^{141}$ Forcible sodomy is penetrating a person's mouth or anus with the sexual organ of another by force and without consent. ${ }^{142}$ To sum, in this study, penetrative sexual assaults include rape (6E1), aggravated sexual assault (6E3), and forcible sodomy (6F).

The military's scheme had four non-penetrative offenses: aggravated sexual contact, abusive sexual contact, wrongful sexual

${ }^{138}$ See Estrich, supra note 73, at 1147-57.

${ }^{139}$ MCM, supra note 105, at app. 28.

${ }^{140}$ Id. at app. 28, A29-3 (2012).

${ }^{141}$ See 10 U.S.C.A. § 925 (2012).

${ }^{142}$ Id.; MCM, supra note 105, at pt. IV, ๆ 51.b, c. 
contact, and indecent assault. The first two are consistent with the Michigan model, where aggravated sexual contact involves the same high degree of force found in rape and abusive sexual contact involves the same lower degree of force found in aggravated sexual assault. ${ }^{143}$ For both, the required sexual activity is an intentional touching, directly or through clothing, of the genitalia, anus, groin, breast, inner thigh, or buttocks of another, or intentionally causing the victim to touch those body parts of someone else coupled with an intent to abuse, humiliate, or degrade any person, or to arouse the sexual desire of any person. ${ }^{144}$ These offenses would capture contact (without penetration) by the penis to the mouth or anus of the victim, or penetration of the mouth or anus by an object other than a penis (if the addition intent requirement was met).

For the third offense, wrongful sexual contact, the sexual activity is the same as the previous two, but no force is required. ${ }^{145}$ Touching without permission is enough. ${ }^{146}$ Last, the dataset contained a few offenses coded as indecent assaults. Indecent assaults were part of the pre2007 scheme. In that scheme, the common law definition of rape was used and required sexual intercourse. The President used the General Article (Article 134) to criminalize nonconsensual sexual assaults, where the act was anything done with the intent to gratify the lust or sexual desires of the accused. ${ }^{147}$ To sum, in this study, non-penetrative sexual assaults are aggravated sexual contact (6C7), abusive sexual contact (6C8), wrongful sexual contact (6C6), and indecent assault (6E1).

\section{Murder}

Murder is the unlawful killing of a human with premeditation, intent to kill or inflict great bodily harm, while engaged in an inherently dangerous act or engaged in a particular felony. ${ }^{148}$ The codes are $5 \mathrm{H} 1$ and 5H7.

\section{Manslaughter}

Manslaughter includes voluntary manslaughter (unlawful killing of another while in the heat of passion), ${ }^{149}$ involuntary manslaughter

\footnotetext{
${ }^{143}$ MCM, supra note 105, at app. 28 A28-1-A28-2.

${ }^{144}$ Id. at app. 28 A28-3.

${ }^{145} I d$. at app. 28 A28-2.

${ }^{146} I d$.

${ }^{147}$ Id. at app. 27 A27-2.

14810 U.S.C.A. § 918 (2012).

14910 U.S.C.A. § 919 (2012).
} 
(unlawful killing of another through culpable negligence or while committing a crime against a person other than those listed for felony murder), ${ }^{150}$ and negligent homicide (unlawful killing of another through simple negligence). ${ }^{151}$ The codes for manslaughter are 5H2, 5H3, 5H4 and $5 \mathrm{H} 5$.

\section{Robbery}

Robbery is the wrongful taking of property from the presence of the victim against the will of the victim through a means of force, violence or putting the victim in fear of immediate or future injury. ${ }^{152}$ The code for robbery is $5 \mathrm{~N}$.

\section{Aggravated and Simple Assaults}

Aggravated assaults include assaults with a dangerous weapon, assaults in which grievous bodily harm is intentionally inflicted, ${ }^{153}$ and maiming. Maiming is the intentional disfigurement or disablement of a person. ${ }^{154}$ The code for aggravated assault is 5C1 and the code for maiming is 5C5. Simple assaults include unlawful demonstrations of violence that creates in the mind of another a reasonable apprehension of immediate bodily harm, and assault consummated by battery, which is offensive, unwanted bodily harm to another that does not involve a dangerous weapon or the intentional infliction of grievous bodily harm. ${ }^{155}$ The code for simple assault is 5C2.

\footnotetext{
${ }^{150} \mathrm{Id}$.

15110 U.S.C.A. § 919 (2012); MCM, supra note 105, at pt. IV, ๆ 85(x).

15210 U.S.C.A. § 922 (2012).

15310 U.S.C.A. § 928 (2012); AR 190-45, supra note 95, at tbl.4-1.

15410 U.S.C.A. § 924 (2012).

15510 U.S.C.A. § 928 (2012); MCM, supra note 105, at pt. IV, ๆ 54.c(1).
} 